\title{
Effect of Stressed Skin Action on the Behaviour of Cold- Formed Steel Portal Frames
}

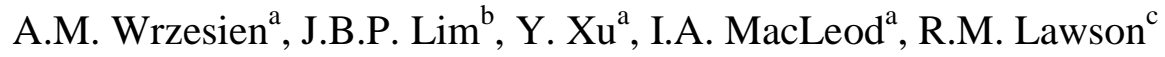 \\ Corresponding author: J.B.P. Lim \\ Email: james.lim@auckland.ac.nz \\ ${ }^{a}$ Department of Civil and Environmental Engineering, University of Strathclyde Glasgow, James Weir \\ Building Level 5, 75 Montrose Street, Glasgow, G1 1XJ, UK \\ ${ }^{b}$ Department of Civil and Environmental Engineering, Faculty of Engineering, The University of Auckland, \\ Auckland 1010, NZ \\ ${ }^{c}$ Department of Civil and Environmental Engineering (C5), Faculty of Engineering and Physical Sciences, \\ University of Surrey, Guildford, GU2 7XH, UK
}

This paper describes a series of six full-scale laboratory tests conducted on coldformed steel portal frame buildings in order to investigate the effects of joint flexibility and stressed skin diaphragm action. The frames used for the laboratory tests were of $6 \mathrm{~m}$ span, $3 \mathrm{~m}$ height, $10^{\circ}$ pitch and the frame spacing was $3 \mathrm{~m}$. Vertical loading was applied in two tests, and horizontal loading was applied in another four tests. The laboratory test set-up represented a building having two gable frames and two internal frames. Tests were conducted on frames having two joint types, both with and without roof sheeting. It was shown that as a result of stressed skin action, the internal frame with roof sheeting resisted approximately three times more horizontal load than the bare frame and the deflection of the internal frame was reduced by $90 \%$ relative to the bare frame. When the difference in loads between 2D (bare frame model) and 3D (stressed skin model) were considered, it was shown that the joint flexibility of the frame has a significant effect on the load transfer between frames through the roof sheeting. It was found that the 'true' loads transferred to the gable frames are between three and seven times higher than the loads deriving from tributary area. By using stressed skin analysis, it is possible to assess the shear force in the roof sheeting so that damage to the fixings is prevented and a more economical design is possible.

Keywords: Cold-formed steel, portal frames, stressed skin action 


\section{Introduction}

Portal frame buildings composed entirely of cold-formed steel (see Fig.1), with spans of up to $20 \mathrm{~m}$, frame spacings up to $4 \mathrm{~m}$ and subject to relatively light loading, can be a viable alternative to conventional hot-rolled steel frames [1-6]. Uses of cold-formed steel portal frames include light industrial, sports and agricultural buildings. In such lightweight steel portal frames, channel-sections are used for the column and rafter members, and top-hat sections may be used for the purlins and side rails (see Fig.2). Top-hat sections are considered to be more efficient than zed-purlins for cold-formed steel portal frames where the frame spacings (or purlin spans) are in the range of $3-4.5 \mathrm{~m}$, compared with $6 \mathrm{~m}$ for conventional hot-rolled steel frames. They are also much stiffer than zedpurlins in terms of transferring shear load to the roofing (see Fig.2) [7].

Principally under horizontal load, the roof sheeting is known to act as a shear diaphragm (see Fig.3) [8] and by this means, loads are transferred to the end gables that should be designed to resist these forces. This stiffening effect, referred to as stressed skin or diaphragm action [9-14], explains why a clad frame behaves differently from a bare frame. Design recommendations on stressed skin action were first published by ECCS TC17 [15] and further extended by Davies and Bryan [11]. Other contributors were: Bates et al. [16], Bryan and Moshin [17], Strnad and Pirner [18], Davies et al. [12], Heldt and Mahendran [19] and Mahendran and Moor [20]. It should be noted that this research focused on hot-rolled steel portal frames in which the haunched eaves and apex joints can be classified as rigid.

In practice, however, the effects of stressed skin action are often ignored by designers of hot-rolled steel portal frames. However, cold-formed steel portal frames have more flexible joints [21] and also use relatively stiffer top-hat purlins, which means that not including the effects of stressed skin action could lead to roof failure at 
serviceability loads (see Fig.4) [22]. This could lead to excessive tearing of the fixings and water leakage into the building [13].

3D structural analysis is now a standard tool for designing complex structures as it gives a more accurate representation of the structural behaviour. However, portal frame buildings are still predominantly modelled as 2D bare frames [23]. An exception is where seismic actions have to be considered, which has been highlighted in research on seismic design of cold-formed steel frames [24-28].

Furthermore, for cold-formed steel portal frames, steel designers often refer to guidance for equivalent hot-rolled steel frames [29] in terms of deflection limits of bare frames, but these are discretionary. As a result, designers sometimes relax these deflection limits to achieve a more economical design under the assumption that the roof panel will reduce the deflections, possibly by as much as $50 \%$. However, the effect of relaxing deflection limits can lead to lighter and more flexible internal frames based on 2D design. This results in an underestimation of the forces in roofing and hence can lead to an under-design of the gable end-frames. Fig. $4 \mathrm{~b}$ shows the consequences of diaphragm action loads on the gable rafter. This is even more important when the joint rotation adds to frame flexibility. Joint rotation in cold-formed steel portal frames is associated with the bearing of the mechanical fasteners (generally bolts) acting in shear on relatively thin steel plates. Designers in the UK often use design guides [30] in which the moment resistance of connections between cold-formed sections is assumed to be governed by bearing resistance of fasteners. The rotational stiffness of a joint and slip due to tolerances in bolt hole is often neglected in the analysis [31]. Investigated joints are therefore similar to what can be found in the practice and the tests using these connections take account of initial slip in the bolts. 
Experimental investigation on portal frames using back-to-back lipped channel sections and bolted joints had been already published [28] but was focused on developing full-strength connections of much greater rotational stiffness than those reported in this paper. The behaviour of a bare frame was investigated in the seismic design context and stressed skin action was not included in this study [28]. The study highlighted importance of component testing in establishing accurate strength and stiffness characteristic of joints which must be included in an analysis model.

In this paper, the results of six full-scale tests on cold-formed steel portal frames are presented. Details of the eaves and apex joints considered in this paper are shown in Fig.5; such joints are typical of those used for cold-formed steel portal frames in practice. As can be seen, the joints are formed using brackets that are bolted between the webs and outer flanges of the cold-formed steel channel-sections. Two different bolt-group sizes are considered for the joints, with each bolt-group size (and therefore bracket size) having a different rotational stiffness. Firstly, tests on frames without roof sheeting are described. Vertical loading was applied in two tests, and horizontal loading was applied in four tests. Secondly, for horizontal loading only, the frame tests were carried out with and without roof sheeting to determine the effect of stressed skin action. The component tests are described separately for both the roof panel and the beam-to-column connections.

Finally, 3D non-linear frame analysis models are presented, which show that the frame behaviour can be predicted accurately if the experimentally determined joint strength and stiffness are used, as well as the stiffness of the roof sheeting. Using these models, the design of cold-formed steel portal frame buildings of $6 \mathrm{~m}$ span, height to eaves of $3 \mathrm{~m}$ and frame spacing of $3 \mathrm{~m}$ are considered in which the design variables are the stiffness of the internal frames and the length of the building. The simplified 2D design assumption, of the load on the end gable being half that of an internal frame is 
shown to be incorrect. It is demonstrated in Fig.20 that if horizontal deflection limits [29] are ignored, such assumption will under-predict the loads acting on end gables by as much as factor of seven. It is concluded that the horizontal loading acting on 1.7 bays should be used as the minimum to design the end gables. This is a factor of 3.4 higher than the simplified assumption that the load on the end gable is half that of an internal frame (see Fig.20c). It is estimated that for building of $12 \mathrm{~m}$ length, $2 \mathrm{D}$ design (see Fig.18) requires $981 \mathrm{~kg}$ of steel which is $42 \%$ more than a portal frame building with joint type B (see Fig.9b). The 'true' loads acting on clad buildings are a function of a length as well as span of the structure and are not accounted for in 2D design. Therefore, 3D analysis is recommended for the design of cold-formed steel portal frames with flexible joints.

\section{Experimental investigation}

\subsection{Details of frames}

Table 1 summarises the six portal frame tests conducted, which are defined as Frames $1-6$. The frames used in all buildings have a span of $6 \mathrm{~m}$, height of $3 \mathrm{~m}$, and pitch of $10^{\circ}$ and the column bases are pinned. The results of the clad frame tests are intended to represent the behaviour of building of $9 \mathrm{~m}$ overall length, having two braced gable frames and internal frames, with a frame spacing of $3 \mathrm{~m}$. Load cells located in the gable braces allowed the load distribution between frames to be determined. Fig.6 shows the nominal dimensions of the channel-sections used for the frames in all six tests. In the internal frames, the channel-sections are placed back-to-back and in the gable frames (including the gable posts) single channel-sections are used. Fig.6b shows the nominal dimensions of the single skin profile used for the roof sheeting. The roof profile has a 
depth of $30 \mathrm{~mm}$ and a nominal thickness of $0.7 \mathrm{~mm}$. Fig.6c shows the nominal dimensions of the top-hat purlins whose thickness is $1.0 \mathrm{~mm}$.

Details of the test general arrangement are shown in Fig.7 and the test setup is shown in Fig.8. Owing to symmetry and also due to laboratory space limitations, only one gable frame and one internal frame were used for each clad frame test.

Frames 1 to 3 used a bolt-group arrangement of $160 \mathrm{~mm} \times 80 \mathrm{~mm}$ for the eaves and apex joints, which are referred to as Joint A. Fig.9a shows details of Joint A and the size of the brackets suit this bolt-group size. Fully threaded M16 bolts were used in $18 \mathrm{~mm}$ diameter bolt-holes. Similarly, the joints in Frames 4 to 6 used a bolt-group size of 280 mm x $80 \mathrm{~mm}$ (see Fig.9b). The eaves and apex joints of these buildings are referred to as Joint B.

In Fig.7, the out-of-plane restraints to the gable frame were provided through a set of ties. Load was applied only to the internal frame. The reaction force in each tie was measured by load cells. Linear displacement transducers were used at positions around the frame. Table 2 shows the measured stiffness of the out-of-plane restraints.

For each frame with Joints A and B, one test was conducted with vertical loading and two tests with horizontal loading. For vertical loaded frames, all tests were conducted without roof sheeting, as the effect of stressed skin action for this shallow roof slope can be expected to be negligible. For the case of horizontal loading, one test was conducted with sheeting and one without sheeting.

It should be noted that for the tests conducted without sheeting, no load was transferred to the gable frames from the internal frames to which the load was applied. The results of the tests on the internal frame can therefore be assumed to be identical to a bare frame test. 


\subsubsection{Joint component tests}

Fig.10 shows details of the general arrangement of the four point bending tests used to determine the stiffness and strength of Joints A and B. The total length of each specimen was $3 \mathrm{~m}$. A continuous beam of $3 \mathrm{~m}$ length was also tested so the flexural rigidity of continuous back-to-back sections could be measured accurately rather than calculated from idealised properties. The test on a continuous beam showed that measured flexural rigidity was $33 \%$ less than calculated based on gross section geometry. In all tests, lateral restraints were provided at the supports, at the load points and at midspan. As for the frame test, fully threaded M16 bolts were used in $18 \mathrm{~mm}$ diameter boltholes.

For each test, a coupon was cut from a flat portion of a flange of each cold-rolled channel section. The coupons of members failing first were subject to tensile tests. The mechanical properties of steel are presented in Table 3 and a typical stress-strain curve is shown in Fig.11.

Tests on Joint A were conducted in both the upwards and downwards direction. As the results for loading in both directions were shown to be similar for Joints A, only a single test in the downwards direction was conducted for Joint B. Fig.12 show the variation of moment with rotation of the point coinciding with centre of rotation for Joints A and B. The same characteristic was also calculated using joint rotational stiffness predicted by Zadanfarrokh and Bryan (1992) [21] (see Fig.12). Table 5 summarises the experimental stiffness $\left(\mathrm{S}_{\mathrm{j}, \text { ini,exp }}\right)$, failure load $\left(\mathrm{F}_{\mathrm{T}}\right)$ and moment capacity $\left(\mathrm{M}_{\mathrm{T}}\right)$ determined in each test.

\subsubsection{Roof panel tests}

Fig.13 shows the general arrangement of the laboratory test used to determine the 
shear strength and stiffness of the roof panels. The test procedure was carried out in accordance with BS 5950-9 [9]. The panel was subjected to three initial loading and unloading cycles before being loaded to failure. The details of an experimental study are presented in Wrzesien et al. 2009 [7].

Self-drilling self-tapping screws of $5.5 \mathrm{~mm}$ diameter with washers and seals were used for fixing the sheeting to the purlins. Self-drilling self-tapping screws of $6.3 \mathrm{~mm}$ diameter, both with and without washers, were used to fix the seams and also to fix the purlin to the rafters. The shear strength and slip of sheet-to-purlin fasteners, seam fasteners and the design resistance and flexibility of the purlin-to-rafter connection were established experimentally as data for some of them were not covered by existing design recommendations $[9,32]$. The characteristic values based on five repeated tests are given in Table 4. The mechanical properties of steel are presented in Table 3 and typical stressstrain curves are shown in Fig.11.

Fig.14 shows the experimental load-deflection curve in which the shear stiffness of the roof panel is converted into an equivalent stiffness of a diagonal spring between the eaves and apex of the frame. The mode of failure observed was a combination of end sheet-to-purlin connection failure and seam failure.

The prediction of a shear stiffness and resistance using design methods [9, 32] is also shown in Fig.14. The geometry of the panel and the fixing arrangement is presented in Fig.13. The experimental shear resistance was approximately three times greater than the calculated design value and the shear stiffness of a panel was approximately one and half times greater than calculated values using the design method $[9,32]$. 


\subsection{Full-scale frame test results}

Load cycles to eliminate the initial bolt slip from the frame were not conducted, as any bolt-hole elongation would not be recoverable and it was considered that the first load cycle is representative of real portal frame structures. All bolts were lightly tightened with a spanner to minimise the effects of friction.

The initial slope of the roof and verticality of the columns were measured using a digital inclinometer and the deflection was set to zero at this position. The values of initial sag of the rafter as well as horizontal displacement of the top of the column under self-weight were calculated based on the difference in angle between perfect and measured geometry.

The same load was applied to each jack until the failure of the structure occurred. The load was applied in steps of approximately $0.5 \mathrm{kN}$ and readings were recorded at the end of each load step.

Fig.15 shows the variation of load against apex deflection for the case of vertical loading. As can be seen, the failure load is almost independent of the bolt-group size, as the frame with Joint B failed at a total load of only $4 \%$ greater than frame with Joint A. However, in terms of stiffness, the frame with Joint B was approximately $60 \%$ stiffer that the frame with Joint A. At the failure load, the eaves joint failed on the column side (see Fig.15), with a mode of failure similar to that observed in the joint component test (see Fig.12).

Fig.16a and $\mathrm{b}$ show the variation of the total load against horizontal deflection of bare horizontally loaded frames with joint types A and B. Again, there is little difference in the failure load of the bare frames as the building with Joint A failed at a load of 18.0 $\mathrm{kN}$, while the building with Joint $\mathrm{B}$ failed at $17.5 \mathrm{kN}$.

Fig.16 also shows the variation of load against horizontal deflection of horizontally 
loaded frames with roof sheeting. There is again little difference in the failure load of the clad frames; the frame with Joint A failed at a total load of $54.3 \mathrm{kN}$, while the frame with Joint B failed at $58.8 \mathrm{kN}$. However, the failure load had increased by almost a factor of three compared with the failure load of the frame with no roof sheeting. Furthermore, the stiffness of the frame increased by almost a factor of ten relative to the bare frame. In both tests, failure of the roof panels occurred together with severe deformations of the purlins (as shown in Fig.4).

\section{Frame analysis}

The non-linear elastic frame analysis program Robot Structural Analysis Professional 2010 [33] was used for the numerical studies. In general, cold-formed steel frames are not suitable for plastic design as they are made using Class 4 sections that are susceptible to local and distortional buckling. Fig.17 shows details of the beam idealization of the full-scale laboratory test that was used in the model. The beam element used had six degrees of freedom per node. Fifteen elements were used for the columns and thirty for the rafters.

In the beam idealization, the rotational stiffness of joints was modelled using the experimentally determined moment-rotation curve of the joints (see Fig.12). This was idealised as a bi-linear rotational spring which was placed at the centre of gravity of the bolt-group following an elastic design method. The Instantaneous Centre of Rotations of eccentrically loaded bolt-groups [34] were ignored as they could not be included in the beam idealisation. Stressed skin action was modelled using tension-only bracing members using the experimentally determined load-deflection curve of the roof panel (see Fig.14). As can be seen in Fig.17, the purlins and side rails were not modelled. The edge beams connecting the gable frame to the internal frames were idealised as having no 
bending stiffness and so only carry axial load. As the effect of the axial stiffness of the top-hat edge purlin on roof panel shear stiffness was already included in the test data, a high axial stiffness was used to represent the purlins in the beam idealisation, so this effect was not considered twice. The beam idealisation of the roof panel was calibrated against the results of the roof panel tests in shear.

The frame analysis results for the case of the vertical loading are shown in Fig.15. Good agreement against the test results was obtained for the buildings with both joint type A and B. As may be expected, the frame analysis slightly over-predicted the failure load as the effect of axial forces was not considered. The experimentally determined bending resistances of the joints and continuous members were used as limiting factors in the frame analysis. Although the effect of axial load is not significant for the given geometry and lateral restraint conditions, the effect should be considered in a frame design using cold-formed steel members [28].

Fig.16a and $\mathrm{b}$ also show the experimental and frame analysis results for the case of the horizontal loading with no roof sheeting, and in this case, the frame analysis results under-predicted both the stiffness and strength of the frames. However, for an internal frame in a clad building with roof sheeting, the agreement in terms of deflections under horizontal load was good (see Fig.16). Good agreement was also observed between forces measured during experiments and those predicted by frame analysis.

\section{Frame design}

\subsection{Investigation of building geometry}

Using the beam idealization described in Section 3, six buildings having 3 to 8 bays were analysed for both ultimate and serviceability limit state design in accordance 
with Eurocode 1 loading. The span, height to eaves, roof pitch and frame spacing were the same and only the length of the building was increased. The building length is expressed as length-to-span ratio ranging from 1.5 (i.e. $3 \times 3 \mathrm{~m}$ bay) to 4 (i.e. $8 \times 3 \mathrm{~m}$ bay). The size of the sheeting panel was therefore kept similar to the component test so accurate experimental strength and stiffness characteristic can be used.

The design process was repeated for each of joint types $\mathrm{A}, \mathrm{B}$ and $\mathrm{C}$, in which a new Joint $\mathrm{C}$ was designed to satisfy horizontal deflection requirement in bare frame analysis [29], and is shown in Fig.18 . Back-to-back channel sections of $300 \mathrm{~mm}$ depth and $2.5 \mathrm{~mm}$ thickness were used for columns and rafters of the internal frames. The gable frames were the same as those in buildings with Joint B. A bolt-group size of $620 \mathrm{~mm} \mathrm{x}$ $208 \mathrm{~mm}$ was used, comprising five bolts in two rows (see Fig.18). The rotational stiffness of such joint was calculated to be $7358 \mathrm{kNm} / \mathrm{rad}[21,31]$. The joint bending resistances were calculated as $71.4 \mathrm{kNm}[22,31,35]$. A $2 \mathrm{D}$ bare frame analysis of the internal and gable frames was also conducted for comparison with the clad frames.

\subsection{Load cases and load combinations}

Fig.19 shows the unfactored actions applied to the frame [29]. The permanent $\left(\mathrm{g}_{\mathrm{k}}\right)$, snow $\left(\mathrm{s}_{\mathrm{k}}\right)$ and live loads $\left(\mathrm{q}_{\mathrm{k}}\right)$ are based on loads of $0.18 \mathrm{kN} / \mathrm{m}^{2}, 0.4 \mathrm{kN} / \mathrm{m}^{2}$ and 0.6 $\mathrm{kN} / \mathrm{m}^{2}$, respectively [36-39]. The wind action $\left(\mathrm{w}_{\mathrm{k}}\right)$ is based on a design pressure of 1.0 $\mathrm{kN} / \mathrm{m}^{2}$ on the side face of the building [40, 41]. Such loadings are typical of design to UK design practice.

The internal and gable frames are checked at the ultimate limit state for the following ultimate load combinations (ULCs) [42, 43]:

$$
\begin{aligned}
& U L C 1=1.35 g_{k}+1.5 q_{k} \\
& U L C 2=1.35 g_{k}+1.5 s_{k}+1.5 \times 0.5 w_{k}
\end{aligned}
$$




$$
\begin{aligned}
& U L C 3=1.35 g_{k}+1.5 w_{k}+1.5 \times 0.5 s_{k} \\
& U L C 4=1.0 g_{k}+1.5 w_{k}(\text { for wind uplift })
\end{aligned}
$$

The internal frame and cladding are also checked at the serviceability limit state. For an internal frame, the serviceability deflection limits recommended by the Steel Construction Institute (SCI) [29] are:

- Absolute horizontal deflection of column height/100 (30 $\mathrm{mm}$ for this case)

- Differential horizontal deflection relative to adjacent frame of frame spacing/200 (15 $\mathrm{mm}$ for this case)

- Differential ridge deflection relative to adjacent frame of frame spacing /100 (30 $\mathrm{mm}$ for this case)

It is assumed that the cladding fails the serviceability limit state when the shear force applied to it exceeds $60 \%$ of its shear resistance. This assumption is based on experimental investigations of the cladding panels and prevents permanent deformation of the roof panel at serviceability loads. [7]. The following serviceability load cases (SLCs) are selected as they are considered under vertical and horizontal loads [42, 43]:

$$
\begin{aligned}
& S L C 1=1.0 q_{k} \\
& S L C 2=1.0 w_{k}
\end{aligned}
$$

\subsection{Unity factors based on the designs}

Fig.20 and Fig.21 summarise the unity factors at the ultimate limit state (ULS) for the internal frame, gable frame and sheeting panel. These are defined as the ratio of the applied load to the resistance for the critical mode of failure as follows:

- Internal frame

$$
U F_{3 D}=\frac{M_{j, E d, 3 D}}{M_{T}}
$$




$$
U F_{2 D}=\frac{M_{j, E d, 2 D}}{M_{T}}
$$

- Gable frame

$$
\begin{gathered}
U F_{3 D}=\frac{N_{E d, 3 D}}{N_{t, R d}} \\
U F_{2 D}=\frac{N_{E d, 2 D}}{N_{t, R d}}
\end{gathered}
$$

- Sheeting panel

$$
U F_{3 D}=\frac{V_{d, E d, 3 \mathrm{D}}}{V_{d, T}}
$$

where:

$\mathrm{M}_{\mathrm{j}, \mathrm{Ed}, 3 \mathrm{D},} \mathrm{M}_{\mathrm{j}, \mathrm{Ed}, 2 \mathrm{D}}$ - bending moments acting on the bolt-group centre of rotation based on 3D and 2D frame analysis

$\mathrm{M}_{\mathrm{T}}-$ connection moment resistance obtained in component test (see Table 5)

$\mathrm{N}_{\mathrm{Ed}, 3 \mathrm{D},} \mathrm{N}_{\mathrm{Ed}, 2 \mathrm{D}}-$ tension forces acting on the gable bracing based on $3 \mathrm{D}$ and 2D frame analysis

$\mathrm{N}_{\mathrm{t}, \mathrm{Rd}}$ - design resistance for uniform tension of the bracing member $(26.95 \mathrm{kN})$

$\mathrm{V}_{\mathrm{d}, \mathrm{Ed}, 3 \mathrm{D}}-$ shear force acting on a roof panel next to gable based on 3D analysis

$\mathrm{V}_{\mathrm{d}, \mathrm{T}}$ - shear resistance of a panel obtained in component test (see Fig.14)

The unity factors were calculated based on $3 \mathrm{D}$ analysis $\left(\mathrm{UF}_{3 \mathrm{D}}\right)$ and the results for different length-to-span ratios of the building are marked by the solid lines on the plots. For comparison, the unity factors based on $2 \mathrm{D}$ design $\left(\mathrm{UF}_{2 \mathrm{D}}\right)$ are also presented as horizontal dashed lines. The load under prediction can be identified when the solid line representing 'true' redistributed loads lies above a dashed line. The critical load combinations (see section 4.2) to which unity factors are calculated for both 3D and 2D 
models are also presented. The loads ratios (r) obtained from the 3D model relative to the loads obtained in the $2 \mathrm{D}$ model are presented for the extremes of the analysis (see Fig.20):

- Internal frame

$$
r_{I}=\frac{M_{y, E d, 3 \mathrm{D}}}{M_{y, E d, 2 \mathrm{D}}}
$$

- Gable frame

$$
r_{G}=\frac{N_{E d, 3 \mathrm{D}}}{N_{E d, 2 \mathrm{D}}}
$$

If the load ratio ( $\mathrm{r}$ ) is greater than 1 , the $2 \mathrm{D}$ analysis model is unsafe and loads should be increased by the given factor (i.e. from Fig. $20 \mathrm{c} \mathrm{r}_{\mathrm{G}}=3.38 \times 0.5$ bay $\approx 1.7$ bay). Hence in a $2 \mathrm{D}$ analysis, the gable frame should be designed to resist wind load resulting from 1.7 times that acting on a single bay between frames).

An analogous approach was used in Fig.22 in order to demonstrate the effect of stressed skin action on building deflections. The serviceability limit state (SLS) unity factors and deflection ratios were calculated as follows:

- Live load

$$
\begin{aligned}
& U F_{3 D}=\frac{\delta_{a, 3 \mathrm{D}}}{\delta_{a, \mathrm{SCI}}} \\
& U F_{2 D}=\frac{\delta_{a, 2 \mathrm{D}}}{\delta_{a, \mathrm{SCI}}} \\
& r_{L L}=\frac{\delta_{a, 3 \mathrm{D}}}{\delta_{a, 2 \mathrm{D}}}
\end{aligned}
$$

- Wind load

$$
\begin{aligned}
& U F_{3 D}=\frac{\delta_{e, 3 \mathrm{D}}}{\delta_{e, \mathrm{SCI}}} \\
& U F_{2 D}=\frac{\delta_{e, 2 \mathrm{D}}}{\delta_{e, \mathrm{SCI}}} \\
& r_{W L}=\frac{\delta_{e, 3 \mathrm{D}}}{\delta_{e, 2 \mathrm{D}}}
\end{aligned}
$$


where:

$\delta_{\mathrm{a}, 3 \mathrm{D}}, \delta_{\mathrm{a}, 2 \mathrm{D}}-$ apex vertical deflection under the imposed load based on $3 \mathrm{D}$ and 2D frame analysis

$\delta_{\mathrm{a}, \mathrm{SCI}} \delta_{\mathrm{e}, \mathrm{SCI}}-$ apex and eaves deflection limits [29]

$\delta_{\mathrm{e}, 3 \mathrm{D}}, \delta_{\mathrm{e}, 2 \mathrm{D}}-$ eaves horizontal deflection under the wind load based on 3D and 2D frame analysis

As can be seen, there is little difference between the ULS unity factors for the portal frames with Joint A and B. For the internal frame, the design of the bare frame is shown to be controlled by a combination of wind and snow load (ULC3), but the 3D model shows, that dependent on building length, the load combinations ULC1 and ULC2 are actually critical for frames with Joint A and B. As expected, when stressed skin effects are taken into account, the frame design is controlled by the shear resistance of the roof panel next to the gable (see Fig.21). The critical load combination for shear forces acting on the roof cladding changes from a combination with leading action of snow (ULC2) to a combination with leading action of wind (ULC3) when the length-to-span ratio reaches three. As expected, the longer the building, the higher the shear forces in the roof panels. The shear force in the roof panel is reduced by between $12 \%$ and $5 \%$ when Joint B rather than Joint A is used. In order to meet the SCI deflection limits, the horizontal stiffness of the portal frame must be increased by approximately a factor of ten. By doing so, the shear force in the roof panel is reduced significantly (see Fig.21).

For the gable frame, it can be seen from Fig.20 that the design of the frame is controlled by the resistance of the gable bracing irrespective of the joint stiffness in the frames. In all cases, a 2D analysis under-estimates the forces in the gable frame by a factor of three for a three bay building and a factor of seven for an eight bay building (see 
Fig.20a and b). If the stiffness of the internal frames is increased to satisfy the SCI serviceability requirements, the shear forces transferred to gables through the roof panels are reduced by approximately $70 \%$. In 3D analysis, the gable frame loading is still over three times higher than in a 2D analysis (see Fig.20c), so if diaphragm action is ignored, the stiffness of the internal frames should be increased further to reduce the forces transferred to the gable frames. Alternatively the gable frame should be designed conservatively for horizontal load resulting from the wind loading on an estimated 1.7 bays regardless of length-to-span ratio. This also means that the in-plane bracing and the foundations to the bracing have to be designed for these higher loads. From Fig.21, it can be concluded that the permanent deformation of the roof cladding does not occur under the working load for buildings with an overall length-to-span ratio less than 2.0 and 2.5 for Joint A and Joint B respectively.

Fig.22 shows the unity factors at the serviceability limit state. As can be seen from Fig.22a and b, diaphragm action reduces the vertical deflection of a three bay building by $36 \%$ compared to that of a bare frame. For horizontal deflections, diaphragm action reduces deflections of a bare frame with Joint $\mathrm{C}$ by $73 \%$ (see Fig.22c). In the case of an eight bay building with the flexible joints (such as Joint A), the horizontal deflection is only $10 \%$ (see Fig.22a) of that calculated for a bare frame due the dominant effect of stressed skin action.

\subsection{Implication for design}

The end gable frames are often designed as braced frames as better economy can be obtained by not using frames with moment-resisting joints. It was shown that in such design cases, the bare gable frame will experience much higher forces due to the effects of diaphragm action and forces acting on it will be under-estimated even if SCI deflection 
limits are adopted. The additional load due diaphragm action may lead to tearing of the roof sheeting or failure of purlin-to-rafter connections at the gable frame and potentially to failure of the end gable itself (see Fig.4b). From Fig.20c, it can be concluded that for buildings of $6 \mathrm{~m}$ span and height to the eves of $3 \mathrm{~m}$ it is appropriate to design end gable frames for wind loading resulting from one to two bays depending on the building length. It was also shown that the horizontal deflection limits in bare frame design must be satisfied as relaxing these limits will lead to even further under-estimation of loads in gable end frames.

In comparison, for hot-rolled portal frames with rigid joints, stressed skin action is less important than in more flexible cold-formed frames and can be conservatively ignored when 2D frame analysis can be used. If the design of portal frames is generally governed by horizontal deflections (e.g. for the design case with Joint C), then it is shown that stressed skin analysis must be carried out.

As the roof construction is constantly evolving, it is also shown that existing design methods need be updated for modern roof systems, such as those with top-hat purlins and composite panels, so that relative flexibility ratio of the frame to the roof system can be accurately assessed (see Fig.14).

Although the design methods $[9,44]$ were developed in the past, these were reexamined in this paper in the context of cold-formed steel frames with flexible joints and it is recommended that 3D non-linear analysis model (FEA) is used for cold-formed steel portal frames for the following reasons:

- Fig.15 and Fig.16 show that the sway and spread flexibilities of bare frames are non-linear relationships due to slip.

- The reduction factors on sway forces (see Table 16 of [9]) are only suitable on the assumption that the gable frames are rigid both in and out-of-plane. The 
flexibility of a gable frame was measured in the tests in this paper (see Table 2) and should not be ignored.

- The assumption in the design methods that wind forces act as point loads at the eaves level, is a simplification, as when the wind load is modelled as a distributed load (see Fig.19c), the maximum bending moment may occur at mid-column height rather than eaves.

A 3D analysis allows the designer to follow 'true' load paths and produce a design which is often more economical. In such designs, however roof sheeting may become a key structural component responsible for the building's stability and so it follows that the stability of the structure can be compromised if the roof sheeting is removed or the stiffness of the roof panel is changed (e.g. by adding openings or replacing sheeting profiles).

\section{Conclusions}

This paper describes a series of six full-scale laboratory tests conducted on coldformed steel portal frames in order to investigate the effects of joint flexibility and stressed skin diaphragm action. The buildings tested were of $6 \mathrm{~m}$ span, $3 \mathrm{~m}$ height, $10^{\circ}$ pitch and $3 \mathrm{~m}$ frame spacing. Two different joints were considered: joint types $\mathrm{A}$ and $\mathrm{B}$, and the stiffness of Joint B was approximately twice that of Joint A.

From the full-scale tests on the bare frames, it was observed that the failure load of buildings with Joints A and B failed at approximately the same load. In terms of stiffness, the bare frame with Joint B was approximately $60 \%$ and $30 \%$ stiffer that the same case with Joint A under vertical load and horizontal load, respectively. However, for the frame with roof cladding, the horizontal stiffness of the building increased by approximately a factor of ten. 
When the experimentally derived data was used to design the building in accordance with the relevant Eurocodes, it was shown that the cladding stiffness cannot be ignored in practice as the loading attracted to the gables may be under-estimated by as much as factor of seven (see Fig.20). This has an important effect on the gable frames which are usually designed for a wind load acting on half a bay according to bare frame model. In order for 2D design to be used safely, horizontal deflection limits more stringent than those recommended by SCI should be adopted or alternatively, the forces acting on the gables should be increased (see Fig.20c).

It is shown that a lighter internal frame can be designed by including diaphragm action in the 3D analysis. For a typical building of $6 \mathrm{~m}$ span and $12 \mathrm{~m}$ length consisting of three internal frames and two end gables, 2D design requires $981 \mathrm{~kg}$ of steel in the framework and when stressed skin action is considered, the overall weight of the steel framework can be reduced by $42 \%$. In such designs, the roof cladding becomes an important structural component in providing lateral stability.

The following general conclusions can be drawn:

- The bare frame model identifies a wind load combination as being critical; including diaphragm action shows that the critical load combination depends on the length-to-span ratio of the building (see Fig.20)

- The bare frame design model may not be safe for designing clad structures as it ignores the additional force in the edge purlins, end cladding and gables (see Fig.20)

- It is proposed that to avoid failure of the end gables, they are designed to resist wind forces equivalent to 1.7 times that acting on a single bay between frames. 
- The effect of the stiffness of the joints on the horizontal deflection of the system when sheeting action is taken into account is less than with a bare frame model that predicts the joint stiffness to be a dominant factor in lateral stiffness. Increasing the rotational stiffness of the joints has a larger effect on vertical deflections e.g. increasing their stiffness by the factor of two (Joints A to B) resulted in an approximately $40 \%$ reduction in apex deflections (see Fig. 22).

\section{Acknowledgements}

Financial support from EPSRC and Capital Steel Buildings is gratefully acknowledged.

\section{References}

[1] Phan DT, Lim JBP, Sha W, Siew CYM, Tanyimboh TT, Issa HK et al. Design optimization of cold-formed steel portal frames taking into account the effect of building topology. Engineering Optimization. 2013;45:415 - 33.

[2] Lim JBP, Nethercot DA. Serviceability design of a cold-formed steel portal frame having semi-rigid joints. Steel \& Composite Structures. 2003;3:451-74.

[3] Wrzesien AM, Lim JBP, Nethercot DA. Optimum joint detail for a general coldformed steel portal frame. Advances in Structural Engineering. 2012;15:1623-39.

[4] Rhodes J, Burns R. Development of a portal frame system on the basis of component testing. 18th International Specialty Conference in Cold-Formed Steel Structures. Orlando, Florida, USA2006.

[5] Johnston RPD, Sonebi M, Lim JBP, Armstrong CG, Wrzesien AM, Abdelal G et al. The Collapse Behaviour of Cold-formed Steel Portal Frames at Elevated Temperatures. Journal of Structural Fire Engineering. 2015;6:77-101.

[6] Johnston RPD, Lim JBP, Lau HH, Xu Y, Sonebi M, Armstrong CG et al. FE investigation of cold-formed steel portal frames in fire. Proceedings of the ICE Structures and Buildings 2015. p. 1-17.

[7] Wrzesien AM, Lim JBP, Lawson RM. The ultimate strength and stiffness of modern roof systems with hat-shaped purlins. In: Chan SL, editor. Sixth International Conference on Advances in Steel Structures Hong Kong, China2009. p. 480-7.

[8] Bryan ER. The stressed skin design of steel buildings, Constrado monographs. London: Crosby Lockwood Staples; 1973.

[9] BS 5950-9. Structural use of steelwork in building. Part 9: Code of practice for stressed skin design. London: British Standards Institution; 1994.

[10] Davies JM. The plastic collapse of framed structures clad with corrugated steel sheeting. ICE Proceedings. 1973;55:23-42. 
[11] Davies JM, Bryan ER. Manual of stressed skin diaphragm design. London: Granada; 1982.

[12] Davies JM, Engel P, Liu TTC, Morris LJ. Realistic modelling of steel portal frame behaviour. The Structural Engineer. 1990;68.

[13] Davies JM, Lawson RM. Stressed skin action of modern steel roof systems. The Structural Engineer. 1999;77:30-5.

[14] Davies JM. Development in stressed skin design. Thin-Walled Structures. 2006;44:1250-60.

[15] ECCS TC17. European recommendations for the stressed skin design of steel structures: European Convention for Constructional Steelwork, ECCS - XVII -77-1E; 1977.

[16] Bates W, Bryan ER, El-Dakhakhni WM. Full-scale tests on a portal frame shed. The Structural Engineer. 1965;43:199-208.

[17] Bryan ER, Mohsin ME. The design and testing of a steel building taking account of the sheeting. The International Association of Bridge and Structural Engineering, 9th Congress, Preliminary Report. Amsterdam: 305-314; 1972.

[18] Strnad M, Pirner M. Static and dynamic full-scale tests on a portal frame structure. The Structural Engineer. 1978;56:45-52.

[19] Heldt TJ, Mahendran M. Full scale experiments of a steel portal frame building. Journal of the Australian Steel Institute, Steel Construction. 1998;32:3-21.

[20] Mahendran M, Moor C. Three-dimensional modeling of steel portal frame buildings. Journal of Structural Engineering. 1999;125 870-8.

[21] Zadanfarrokh F, Bryan ER. Testing and design of bolted connections in cold-formed steel sections. 11th International Specialty Conference on Cold-Formed Steel Structures. St. Louis, Missouri, USA1992. p. 625-62.

[22] Phan DT, Lim JBP, Tanyimboh TT, Wrzesien AM, Sha W, Lawson RM. Optimal design of cold-formed steel portal frames for stressed-skin action using genetic algorithm. Engineering Structures. 2015;93:36-49.

[23] Hairsine RC. Simplified 3D analaysis of portal structures-observations, problems and solutions. The Structural Engineer. 2010;88:25-33.

[24] Calderoni B, De Martino A, Landolfo R, Ghersi A. On the Seismic Resistance of Light Gauge Steel Frames. In: Mazzolani F, Gioncu V, editors. Behaviour of Steel Structures in Seismic Areas STESSA '94. London: E \& FN Spoon; 1995. p. 333-43.

[25] Tremblay R, Stiemer SF. Seismic behavior of single-storey steel structures with a flexible roof diaphragm. Canadian Journal of Civil Engineering. 1996;23:49-62.

[26] Dubina D, Fulop L, Nagy Z, Ungureanu V. Cold-formed Steel Structures for Single Storey Buildings. International Conference on Steel Structures of the 2000's. Istanbul, Turkey2000. p. 191-6.

[27] Dubina D, Ungureanu V, Fulop L, Nagy Z, Larsson H. LINDAB Cold-Formed Steel Structures for Small and Medium Size Non-Residential Buildings in Seismic Zones. The 9th Nordic Steel Construction Conference NSCC2001. Helsinki, Finland2001. p. 463-70.

[28] Stratan A, Nagy Z, Dubina D. Cold-formed steel pitched-roof portal frames of backto-back plain channel sections and bolted joints. Eighteenth International Specialty Conference on Cold-Formed Steel Structures. Orlando, Florida, U.S.A.2006.

[29] SCI P397. Elastic Design of Single-Span Steel Portal Frame Buildings To Eurocode 3. In: Koschmidder DM, Brown DG, editors. Ascot, UK, : The Steel Construction Institute; 2012.

[30] SCI P125. Building Design using Cold Formed Steel Sections: Worked Examples to BS 5950: Part 5: 1987. Ascot, UK,: The Steel Construction Institute; 1993. 
[31] Johnston RP, Wrzesien AM, Lim JBP, Sonebi M, Armstrong CG. The effect of semi-rigid joints on the design of cold-formed steel portal frame structures. Civil and Environmental Research. 2013;5:1-5.

[32] ECCS. European recommendations for the application of metal sheeting acting as a diaphragm. Brussels: European Convention for Constructional Steelwork; 1995.

[33] Autodesk Inc. Autodesk Robot Structural Analysis Professional 2010 Training Manual - Metric Version. 2009.

[34] Crawford SF, Kulak GL. Eccentrically Loaded Bolted Connections. Journal of the Structural Division, ASCE. 1971; 97:765-83.

[35] Dubina D, Stratan A, Ciutina A, Fulop L, Zsolt N. Monotonic and cyclic performance of joints of cold formed steel portal frames. In: Loughlan J, editor. 4th International Conference on Thin-walled structures. Loughborough, UK2004. p. 381-8.

[36] BS EN 1991-1-1:2002. Eurocode 1: Actions on structures - Part 1-1: General actions - Densities, self-weight, imposed loads for buildings (Incorporating corrigenda December 2004 and March 2009). London: British Standard Institution; 2002.

[37] BS EN 1991-1-3:2003. Eurocode 1 - Actions on structures - Part 1-3: General actions - Snow loads (Incorporating corrigenda December 2004 and March 2009) London: British Standard Institution; 2003.

[38] NA to BS EN 1991-1-1:2002. UK National Annex to Eurocode 1: Actions on structures - Part 1-1: General actions - Densities, self-weight, imposed loads for buildings. London: British Standard Institution; 2005.

[39] NA to BS EN 1991-1-3:2003. UK National Annex to Eurocode 1: Actions on structures - Part 1-3: General actions - Snow loads (Incorporating

corrigendum no. 1). London: British Standard Institution; 2005.

[40] BS EN 1991-1-4:2005+A1:2010. Eurocode 1: Actions on structures - Part 1-4: General actions - Wind actions (Incorporating corrigenda July 2009 and January 2010). London: British Standard Institution; 2005.

[41] NA to BS EN 1991-1-4:2005+A1:2010. UK National Annex to Eurocode 1 Actions on structures Part 1-4: General actions - Wind actions (Incorporating National Amendment No. 1). London: British Standard Institution; 2008.

[42] BS EN 1990:2002+A1:2005. Eurocode - Basis of structural design ( Incorporating corrigenda December 2008 and April 2010). London: British Standard Institution; 2002.

[43] NA to BS EN 1990:2002+A1:2005. UK National Annex for Eurocode - Basis of structural design (Incorporating National Amendment No. 1). London: British Standard Institution; 2004.

[44] ECCS TC7. European recommendations for the application of metal sheeting acting as a diaphragm - stressed skin design: European Convention for Constructional Steelwork, ECCS No. 40; 1995.

[45] BS EN 10002-1:2001. Metallic materials - Tensile testing. Part 1: Method of test at ambient temperature. Brussels: European Committee for Standardization; 2001. 
Table 1 Summary of full-scale frame tests

\begin{tabular}{|c|c|c|c|}
\hline Frame & $\begin{array}{l}\text { Joint } \\
\text { type }\end{array}$ & $\begin{array}{l}\text { Direction } \\
\text { of loading }\end{array}$ & $\begin{array}{c}\text { With roof } \\
\text { sheeting }\end{array}$ \\
\hline 1 & \multirow[t]{3}{*}{ A } & Vertical & No \\
\hline 2 & & Horizontal & No \\
\hline 3 & & Horizontal & Yes \\
\hline 4 & \multirow[t]{3}{*}{ B } & Vertical & No \\
\hline 5 & & Horizontal & No \\
\hline 6 & & Horizontal & Yes \\
\hline
\end{tabular}

Table 2 Measured stiffness $\mathrm{k}_{\mathrm{j}}$, of bracing members modelled as bi-linear springs

\begin{tabular}{|c|c|c|c|c|c|c|}
\hline \multirow{2}{*}{$\begin{array}{c}\text { Spring } \\
\text { position }\end{array}$} & $\mathrm{k}_{1}$ & \multicolumn{3}{|c|}{$\begin{array}{c}\text { Frame 3 } \\
\mathrm{D}_{1}\end{array}$} & $\mathrm{k}_{2}$ & \multicolumn{3}{c|}{ Frame 6 } \\
& $\mathrm{kN} / \mathrm{mm}$ & $\mathrm{mm}$ & $\mathrm{kN} / \mathrm{mm}$ & $\mathrm{kN} / \mathrm{mm}$ & $\mathrm{mm}$ & $\mathrm{kN} / \mathrm{mm}$ \\
\hline$\delta_{3 \mathrm{~A}}$ & 1.57 & 3.19 & 0.69 & 0.89 & 5.51 & 0.66 \\
\hline$\delta_{4 \mathrm{~A}}$ & 0.64 & 3.77 & 0.85 & 0.96 & 5.07 & 0.94 \\
\hline$\delta_{3 \mathrm{~B}}$ & 1.13 & 0.84 & 1.39 & 0.89 & 2.37 & 1.73 \\
\hline$\delta_{4 \mathrm{~B}}$ & 1.77 & 1.25 & 1.93 & 1.65 & 2.03 & 2.00 \\
\hline
\end{tabular}

$\mathrm{k}_{1}$ - stiffness in the initial phase of loading

$\mathrm{D}_{1}$ - displacement limiting initial phase of loading

$\mathrm{k}_{2}$ - stiffness in the second phase of loading

Table 3 Steel properties obtained from tensile coupon tests [45]

\begin{tabular}{|c|c|c|c|c|c|c|}
\hline Component & Position & $\begin{array}{c}\text { Number of } \\
\text { tensile tests }\end{array}$ & $\begin{array}{c}\text { Proof } \\
\text { strength }\end{array}$ & $\begin{array}{c}\text { Tensile } \\
\text { strength }\end{array}$ & $\begin{array}{c}\text { Non- } \\
\text { proportional } \\
\text { elongation } \\
\text { at maximum } \\
\text { stress }\end{array}$ & $\begin{array}{c}\text { Elongation } \\
\text { after fracture }\end{array}$ \\
\hline Channel section & $\begin{array}{c}\text { Flat portion of a } \\
\text { flange }\end{array}$ & 3 & 395 & 502 & 15 & $(\%)$ \\
\hline Top-hat purlin & $\begin{array}{c}\text { Flat portion of a } \\
\text { web }\end{array}$ & 3 & 590 & 608 & 4 & 5 \\
\hline Sheeting profile & $\begin{array}{c}\text { Flat portion of a } \\
\text { web }\end{array}$ & 3 & 301 & 380 & 23 & 44 \\
\hline
\end{tabular}

Table 4 Characteristic values established in component tests

\begin{tabular}{|c|c|c|}
\hline Screw connection type & $\begin{array}{c}\text { Shear } \\
\text { resistance } \\
(\mathrm{kN})\end{array}$ & $\begin{array}{c}\text { Shear } \\
\text { flexibility } \\
(\mathrm{mm} / \mathrm{kN})\end{array}$ \\
\hline 5.5mm dia. screw (sheet-to-purlin) & 1.90 & 0.34 \\
\hline 6.3mm dia. screw (seam) & 1.30 & 0.29 \\
\hline 4 x 6.3mm dia. Screws (purlin-to-rafter) & 4.20 & 0.81 \\
\hline
\end{tabular}

Table 5 Summary of results of joint component tests 


\begin{tabular}{|c|c|c|c|c|}
\hline Joints & $\begin{array}{c}\text { Direction of } \\
\text { loading }\end{array}$ & $\begin{array}{c}\mathrm{S}_{\mathrm{j}, \text { ini,exp }} \\
(\mathrm{kNm} / \mathrm{rad})\end{array}$ & $\begin{array}{c}\mathrm{F}_{\mathrm{T}} \\
(\mathrm{kN})\end{array}$ & $\begin{array}{c}\mathrm{M}_{\mathrm{T}} \\
(\mathrm{kNm})\end{array}$ \\
\hline A & Downwards & 601 & 36.33 & 18.17 \\
\hline A & Upwards & 591 & 32.46 & 16.23 \\
\hline B & Downwards & 1229 & 40.61 & 20.30 \\
\hline
\end{tabular}

$\mathrm{S}_{\mathrm{j}, \text { ini,exp }}-$ measured joint rotational stiffness due to bolt bearing

$\mathrm{M}_{\mathrm{T}}$ - moment calculated from $\mathrm{F}_{\mathrm{T}}$

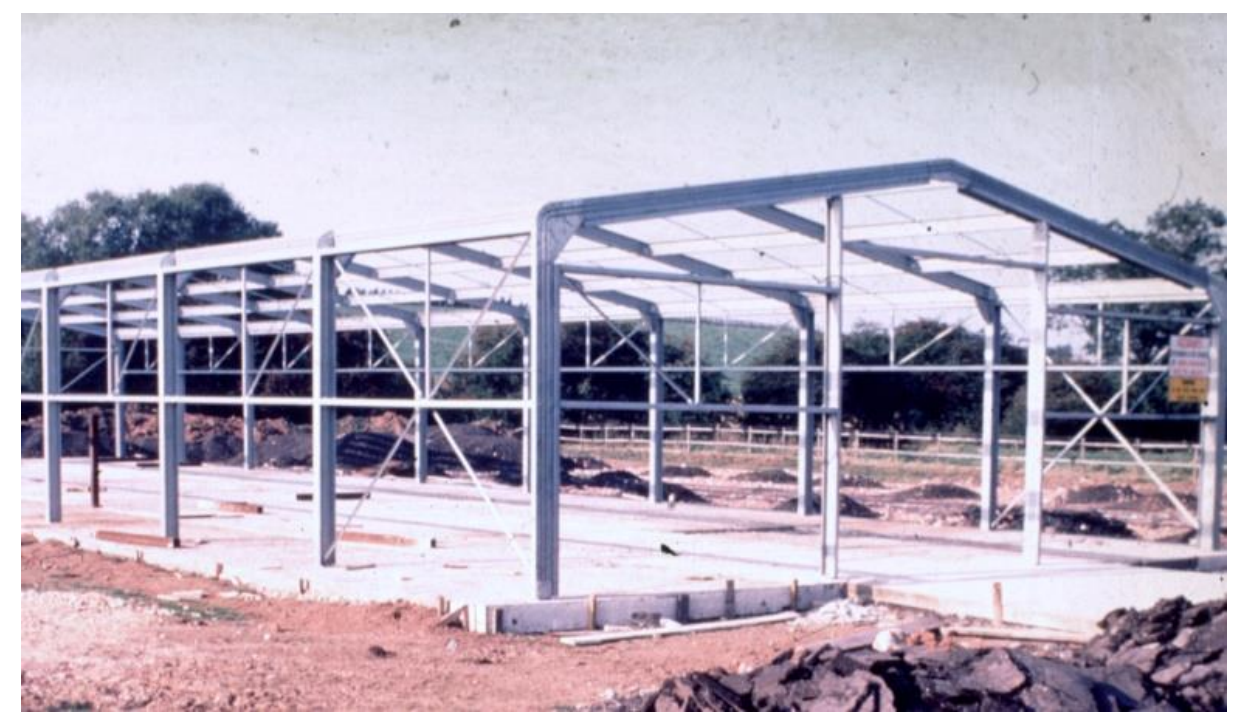

Fig.1 Typical cold-formed steel portal framing system

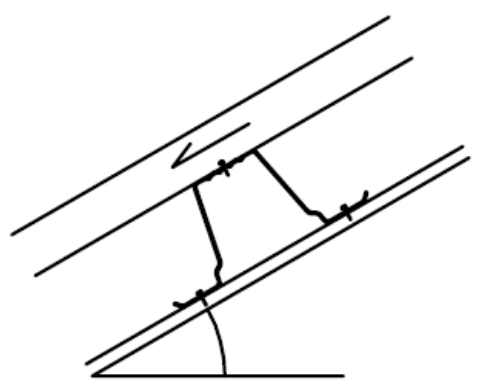

a) Top- hat purlin

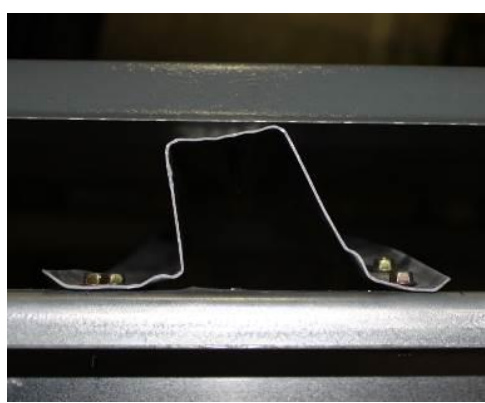

b) Shear deformation due to diphragm action

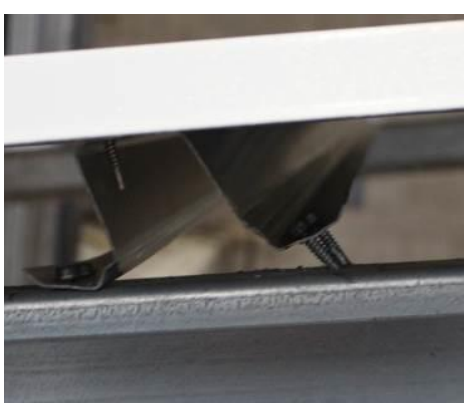

c) Failure of purlinto- end-rafter connection

Fig.2 Behaviour of top-hat sections acting as purlins in a clad frame 


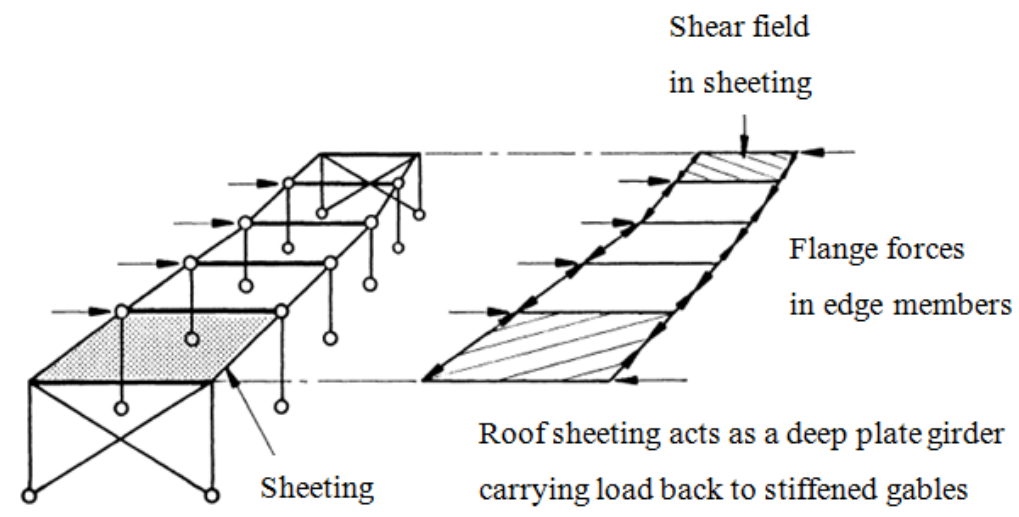

Fig.3 Stressed skin action under horizontal load on buildings (after BS 5950-Part 9 [9])

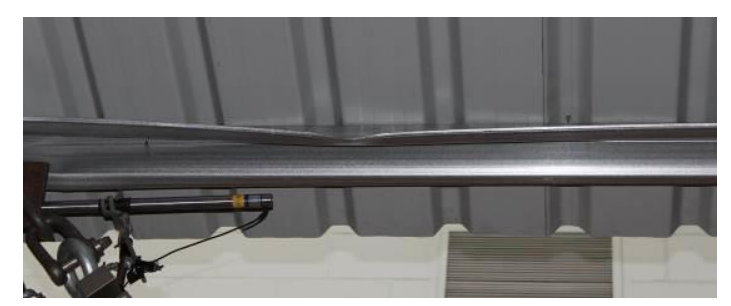

a) Buckling of the edge purlin

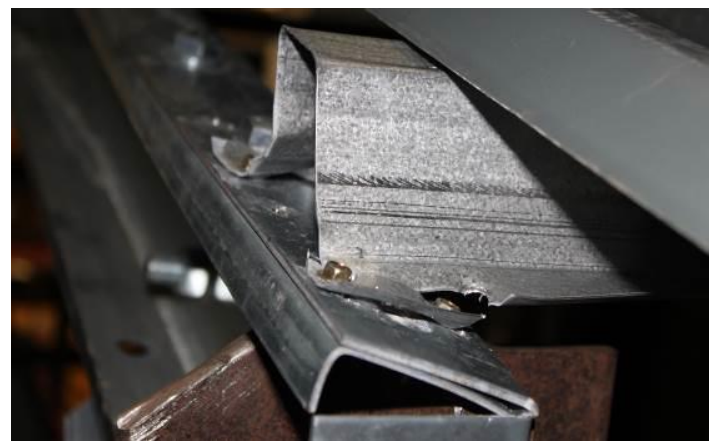

b) Failure of purlin connection and deformation of the gable-frame rafter

Fig.4 Mode of failures observed in clad frame tests

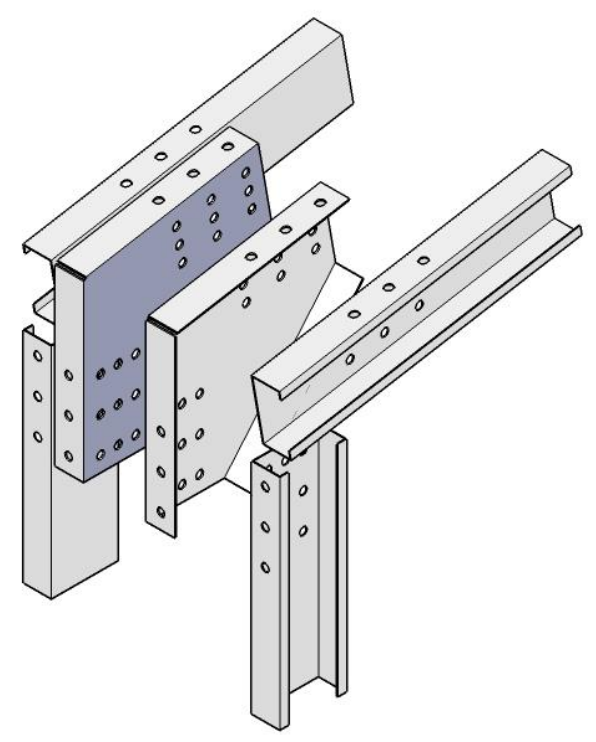

(a) Eaves joint

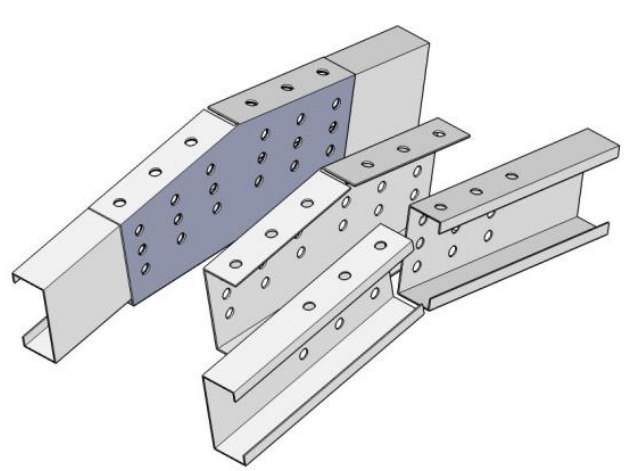

(b) Apex joint 
Fig.5 Details of joints for the cold-formed steel portal framing system

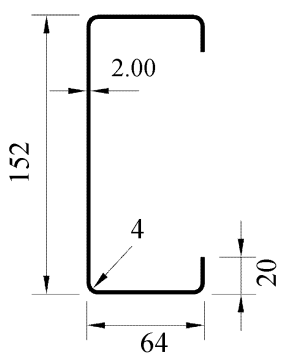

a) Column/rafter

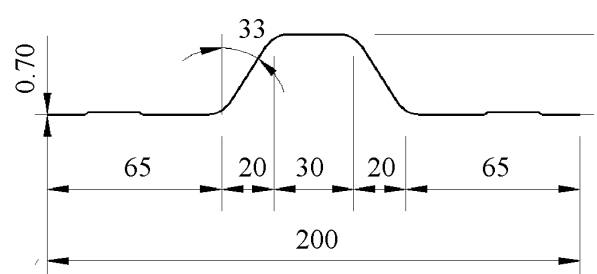

b) Sheeting profile

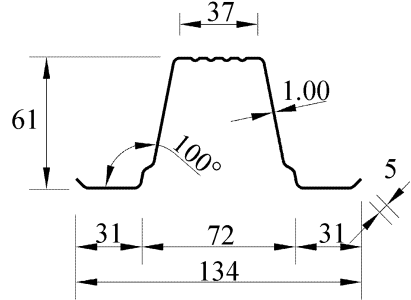

c) Purlin

Fig.6 Nominal dimensions of components used for building tests

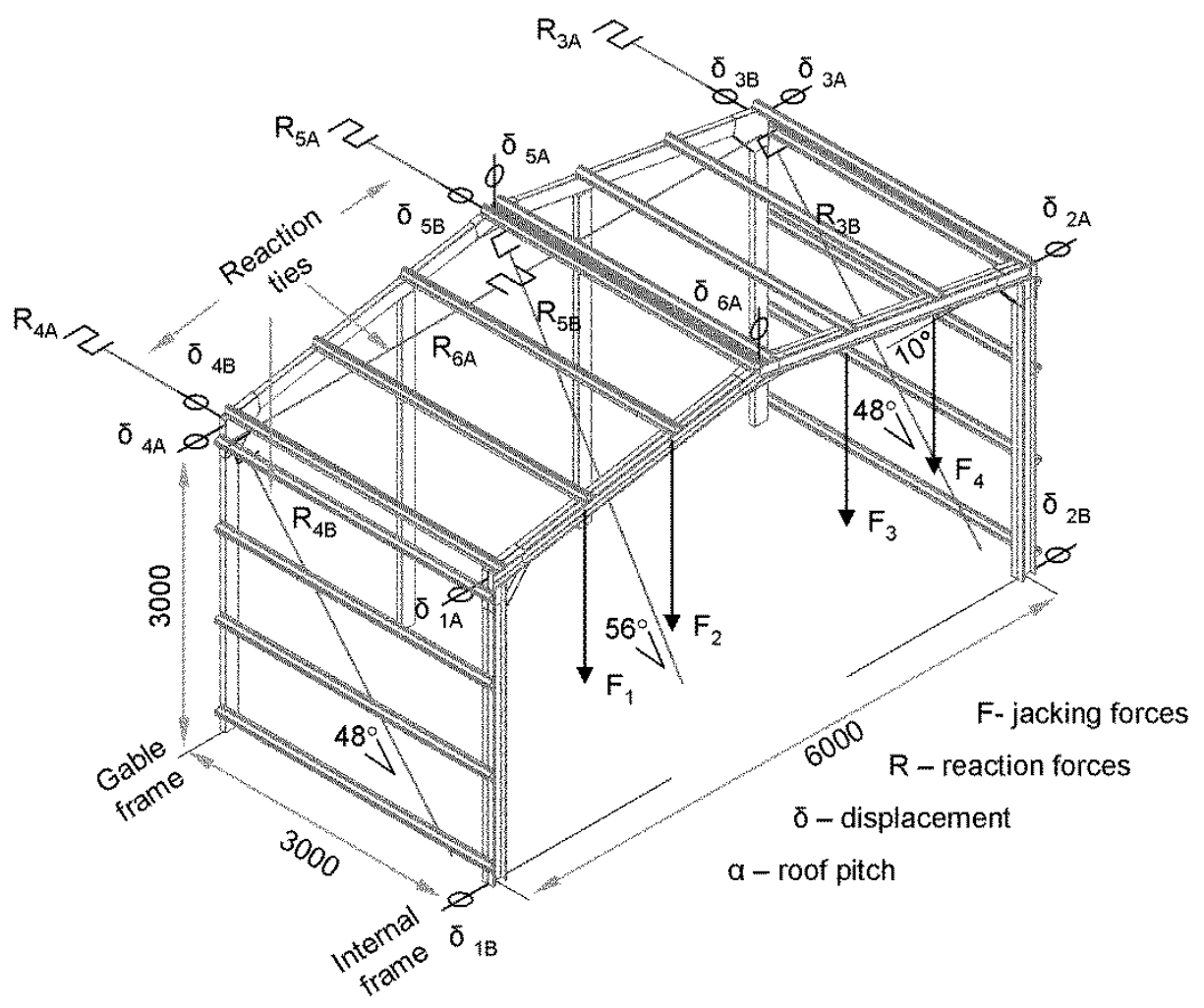

a) Vertical load 


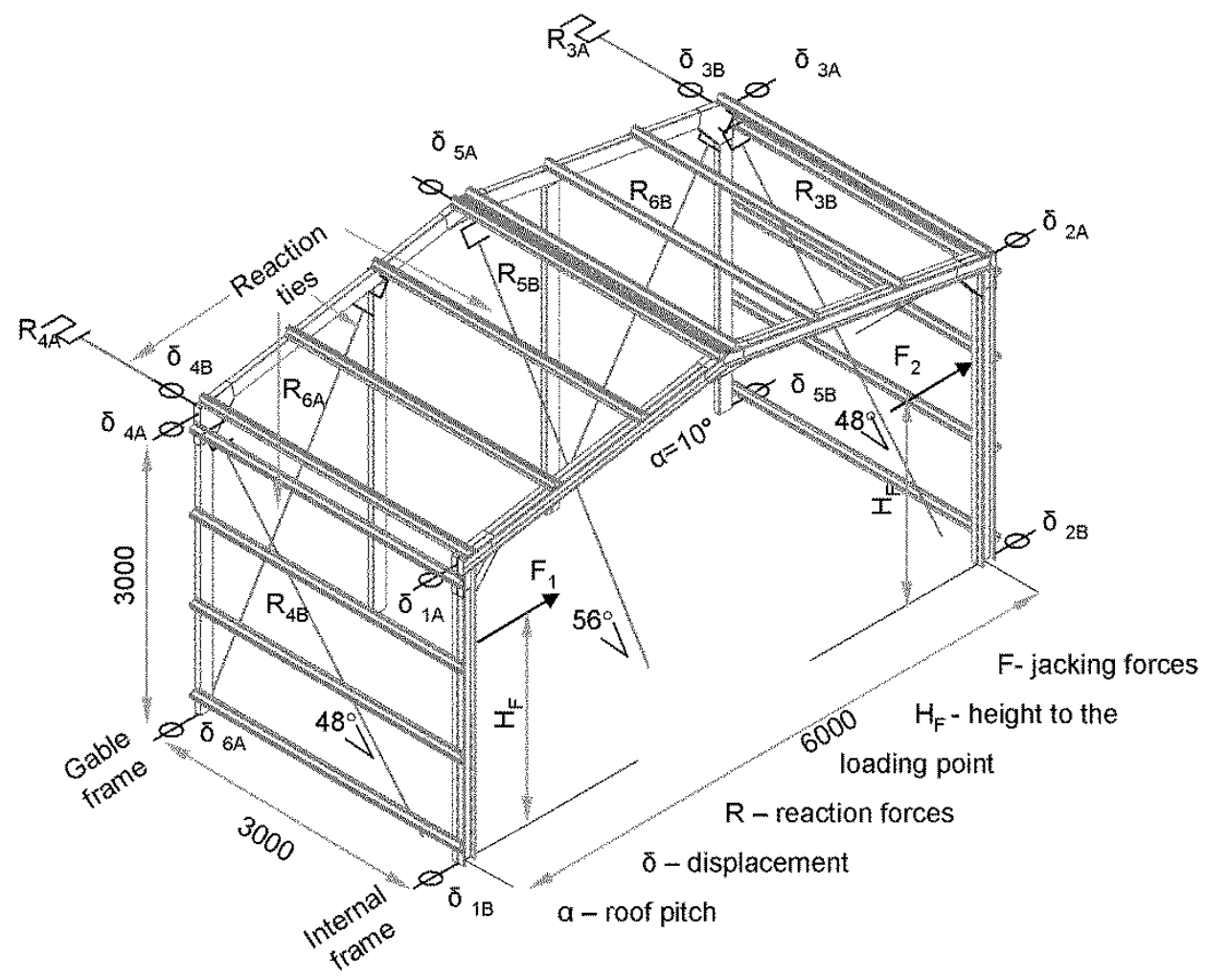

$\mathrm{H}_{\mathrm{F}}=2500 \mathrm{~mm}$ and $2400 \mathrm{~mm}$ for Frame A and Frame $\mathrm{B}$ respectively

b) Horizontal load

Fig.7 General arrangement of full-scale test frame

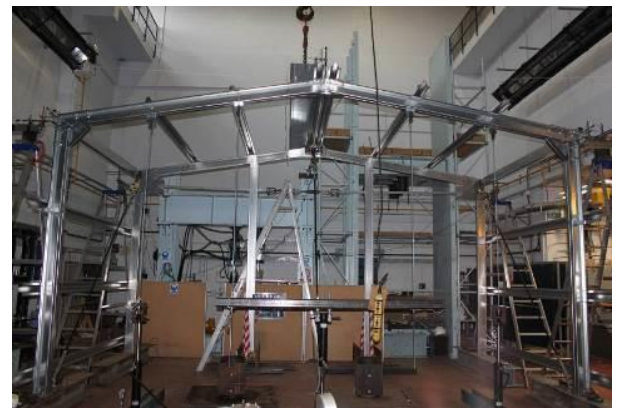

a) Building with no sheeting

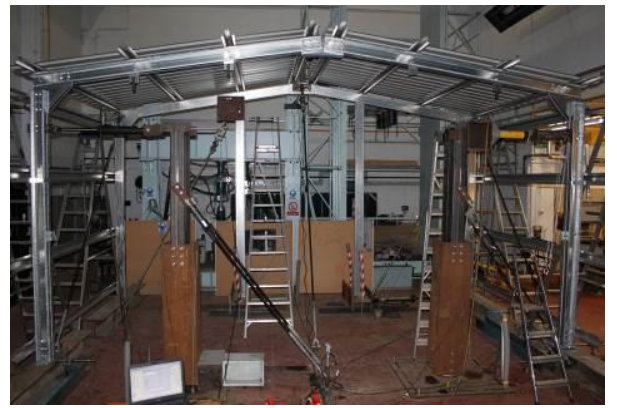

b) Building with roof sheeting

Fig.8 Photograph of full-scale portal frame building tests 

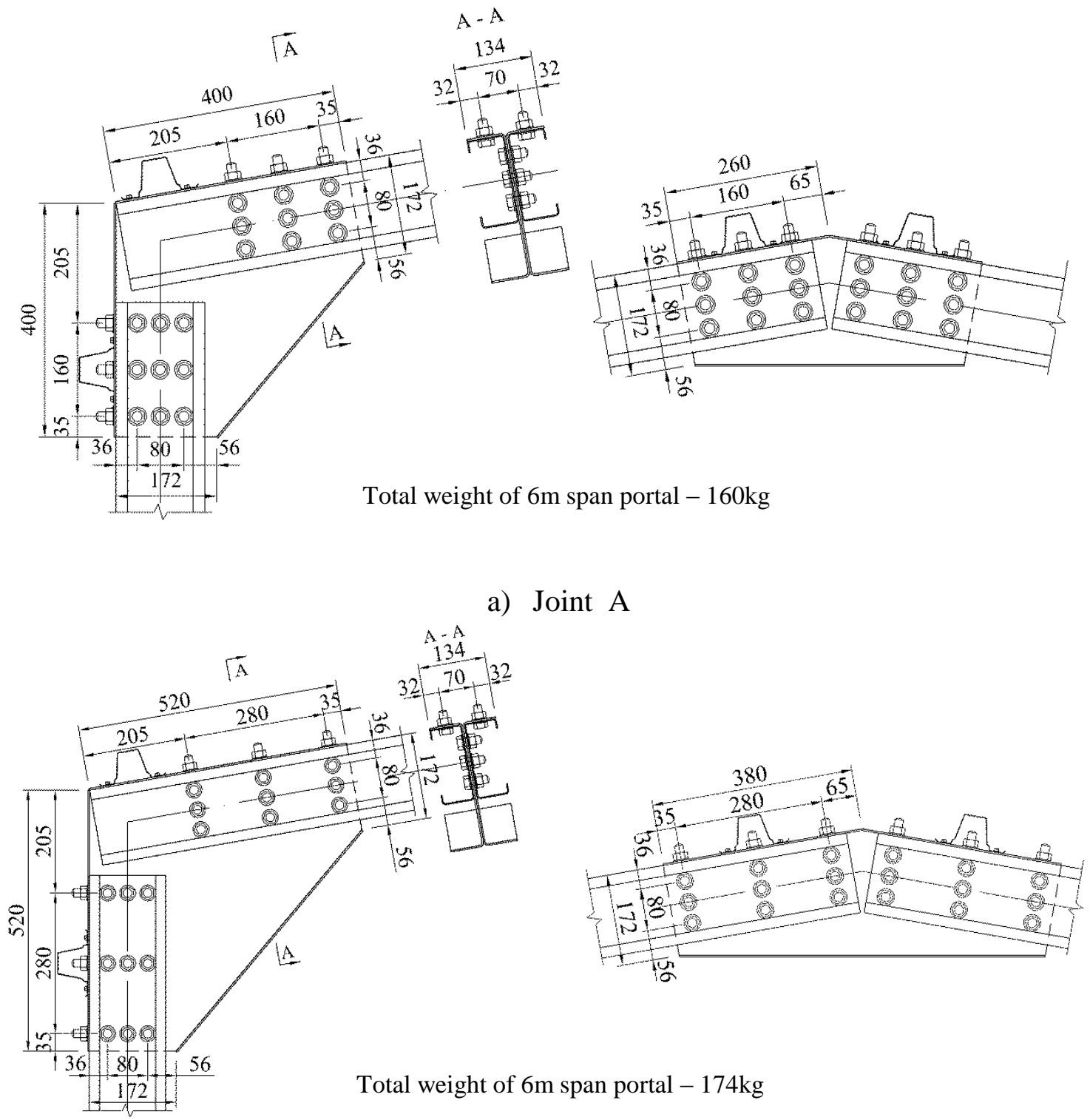

b) Joint B

Fig.9 Details of joint eaves and apex joints types A and B

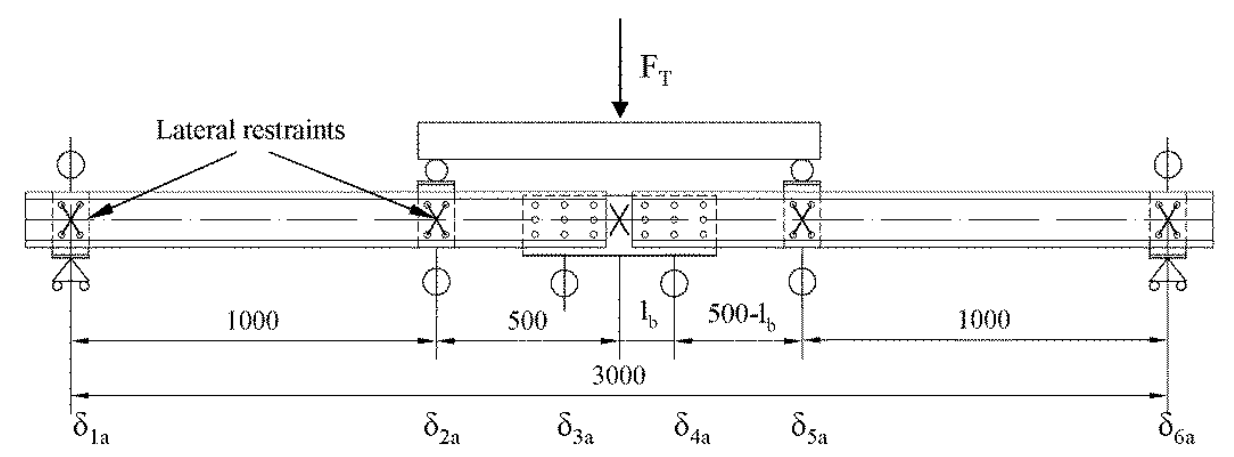

$\delta=$ displacement, $\mathrm{F}_{\mathrm{T}}=$ jacking force, $\mathrm{l}_{\mathrm{b}}=145 \mathrm{~mm}$ and $205 \mathrm{~mm}$ for Joints $\mathrm{A}$ and $\mathrm{B}$, respectively 
Fig.10

Details of general arrangement of joint component tests

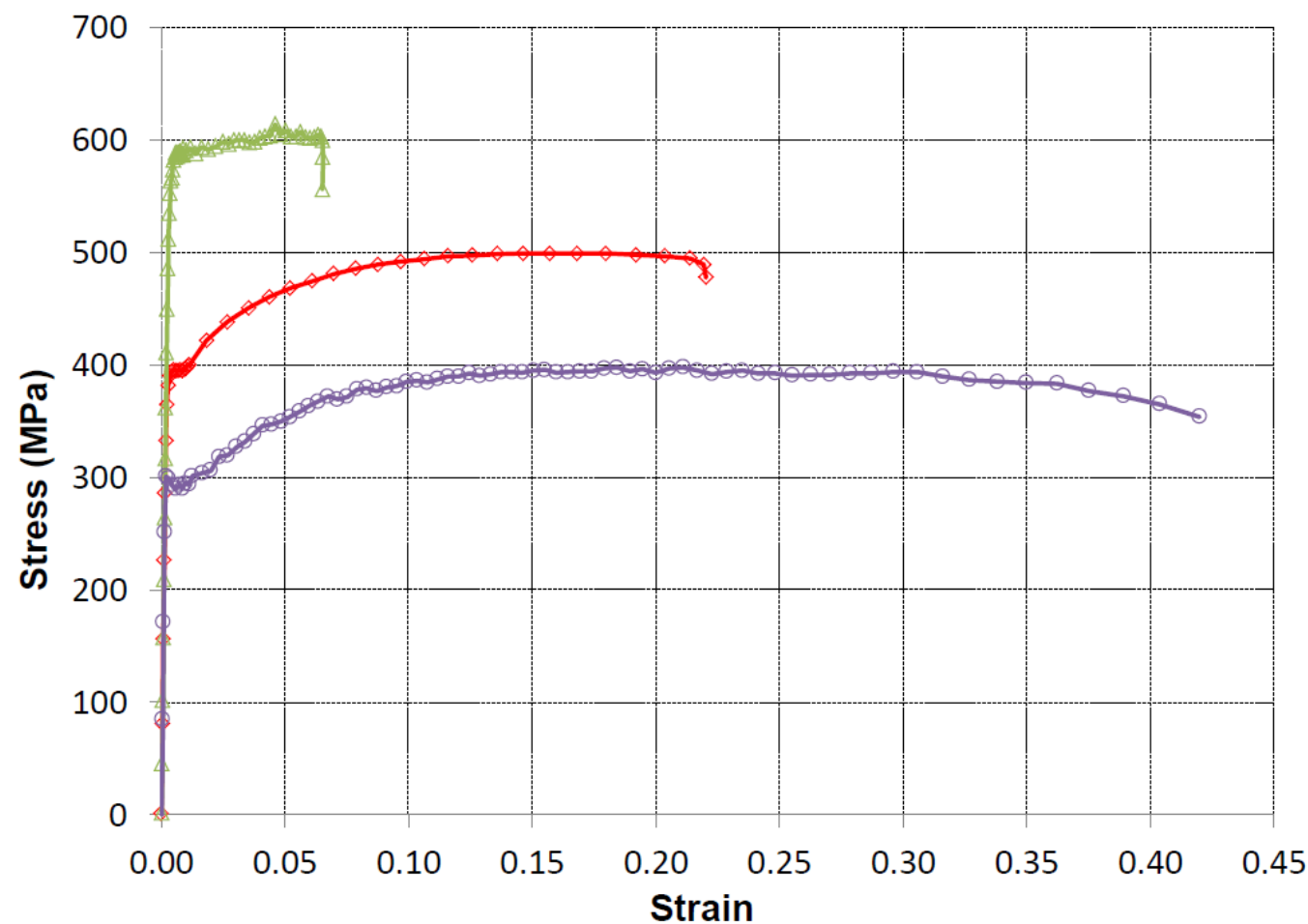

$\multimap$ Channel section $\rightarrow$ Top-hat purlin $\_$Sheeting profile

Fig.11 Typical stress-strain curves for the steel used in the components 

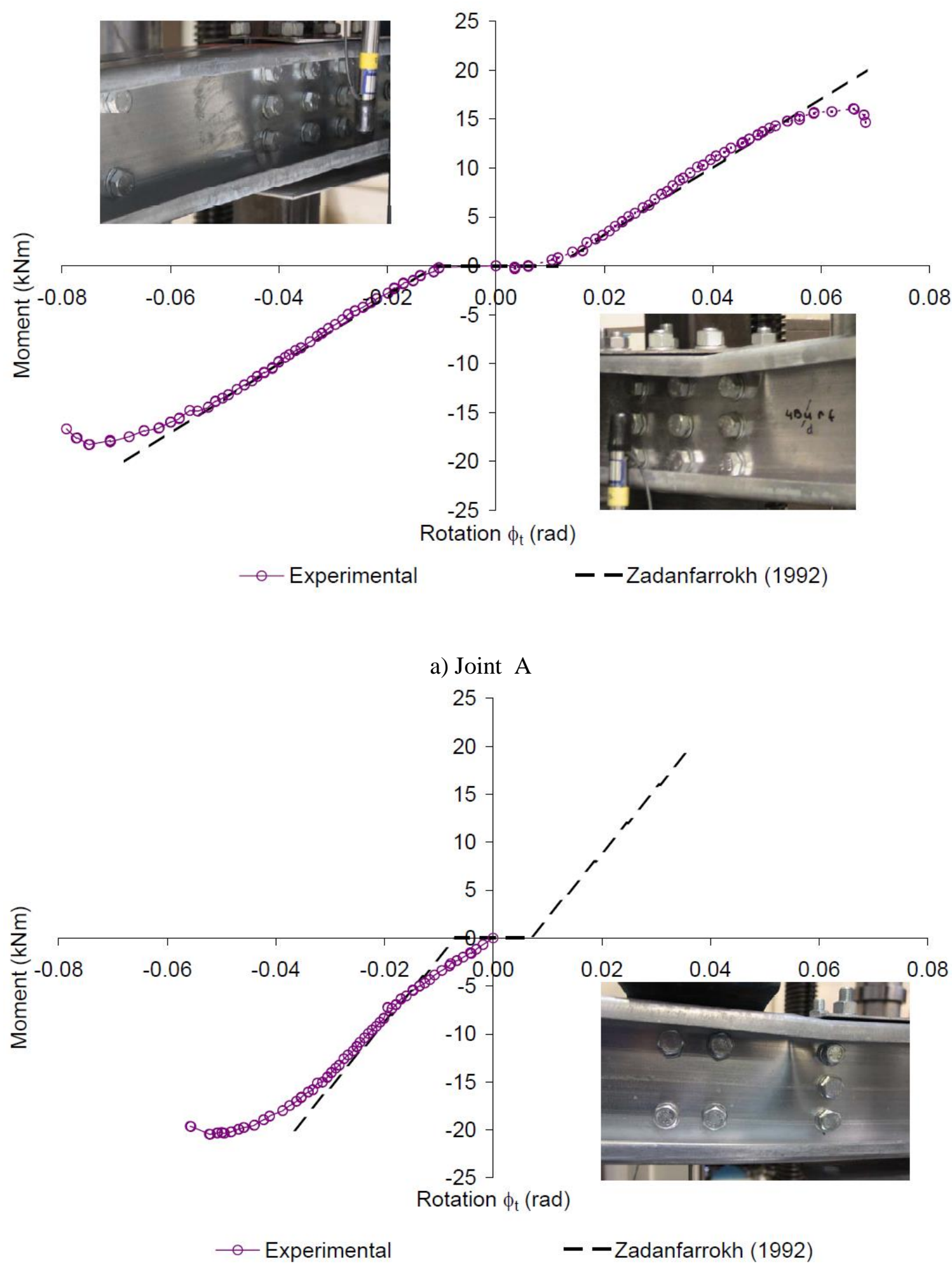

b) Joint B

Fig.12 Variation of moment against rotation for joint A and B component tests 


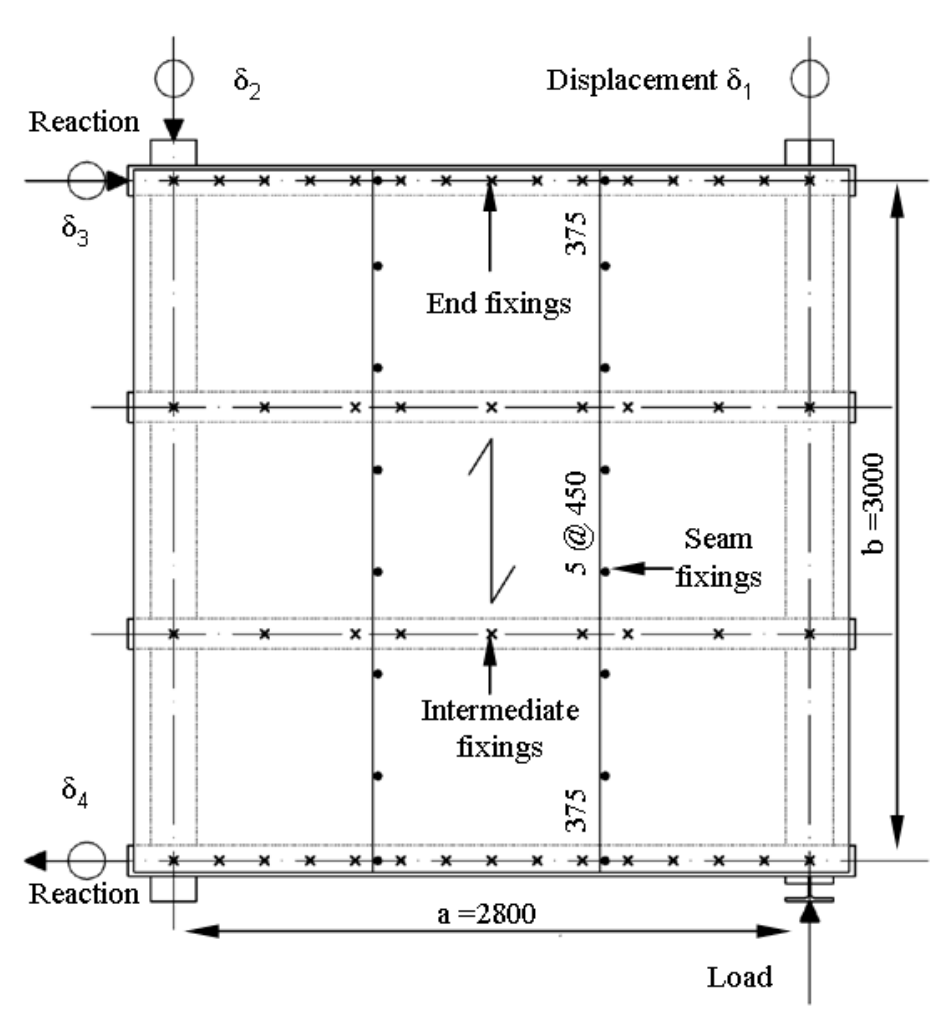

Fig.13 Plan view of the test arrangement of the roof panel

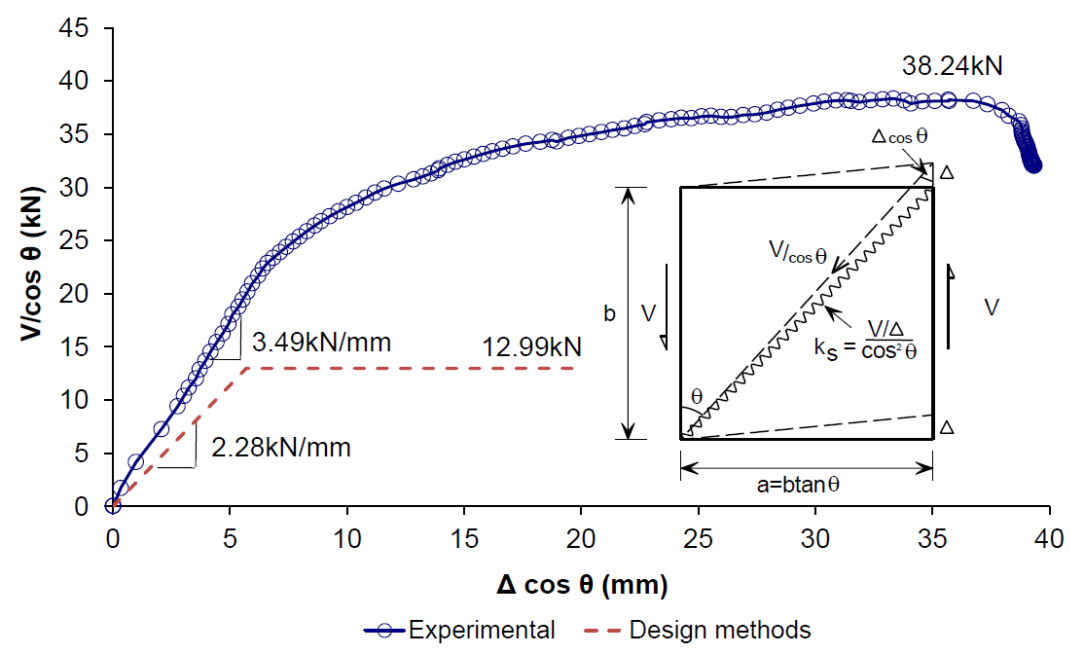

Fig.14 Experimental shear stiffness of the roof panel expressed as diagonal spring stiffness 


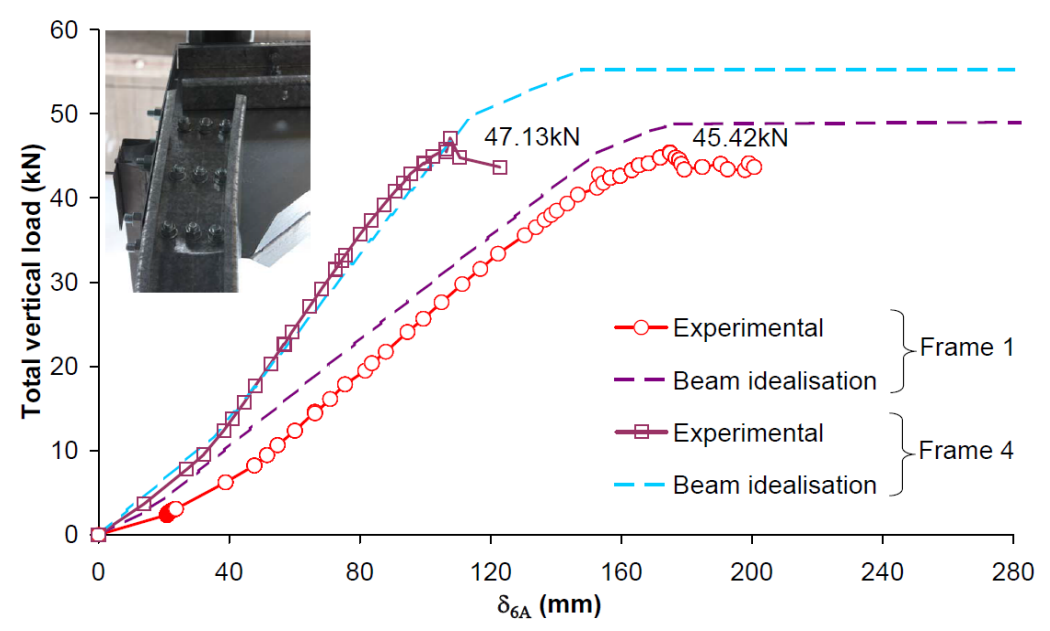

Fig.15 Variation of load against apex deflection for frames loaded in vertical direction (Frames 1 and 4)

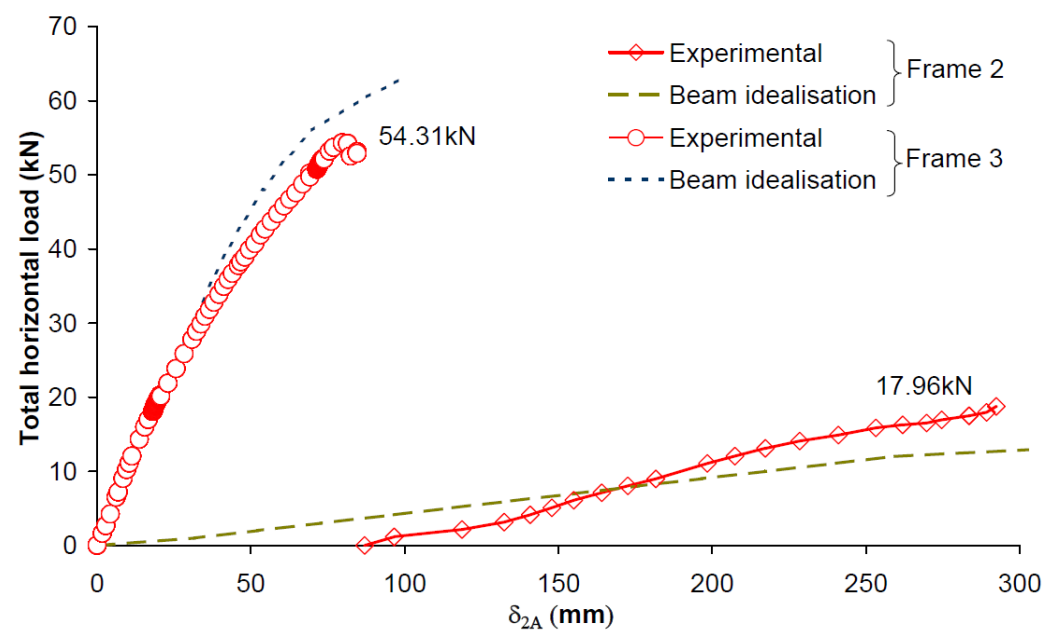

a) Frames 2 and 3

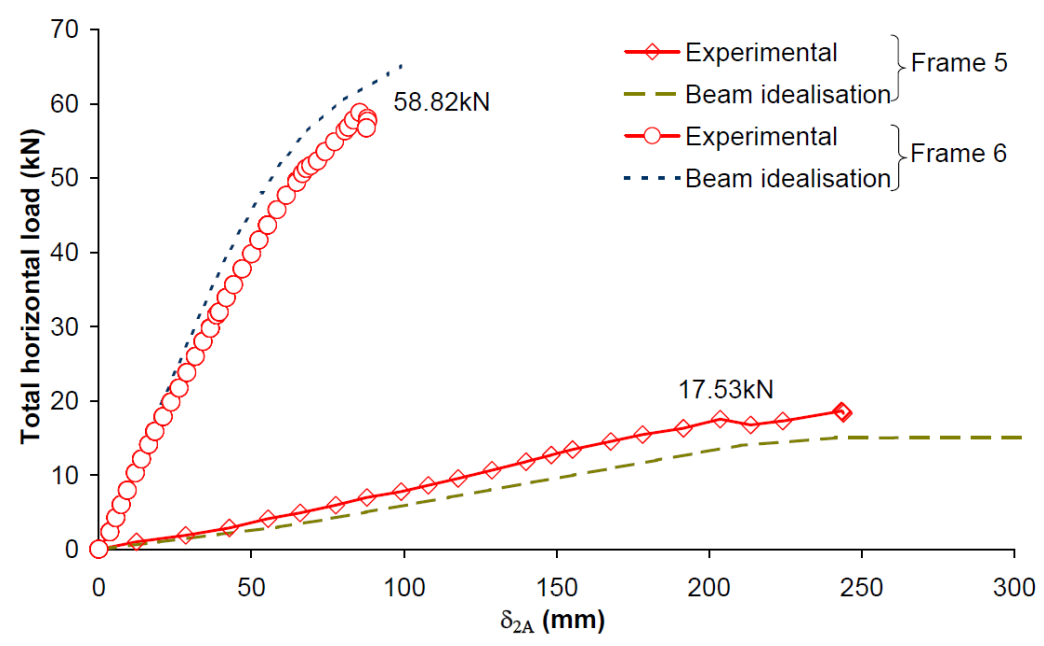

b) Frames 5 and 6

Fig.16 Variation of load against deflection for building with roof sheeting loaded in horizontal direction 


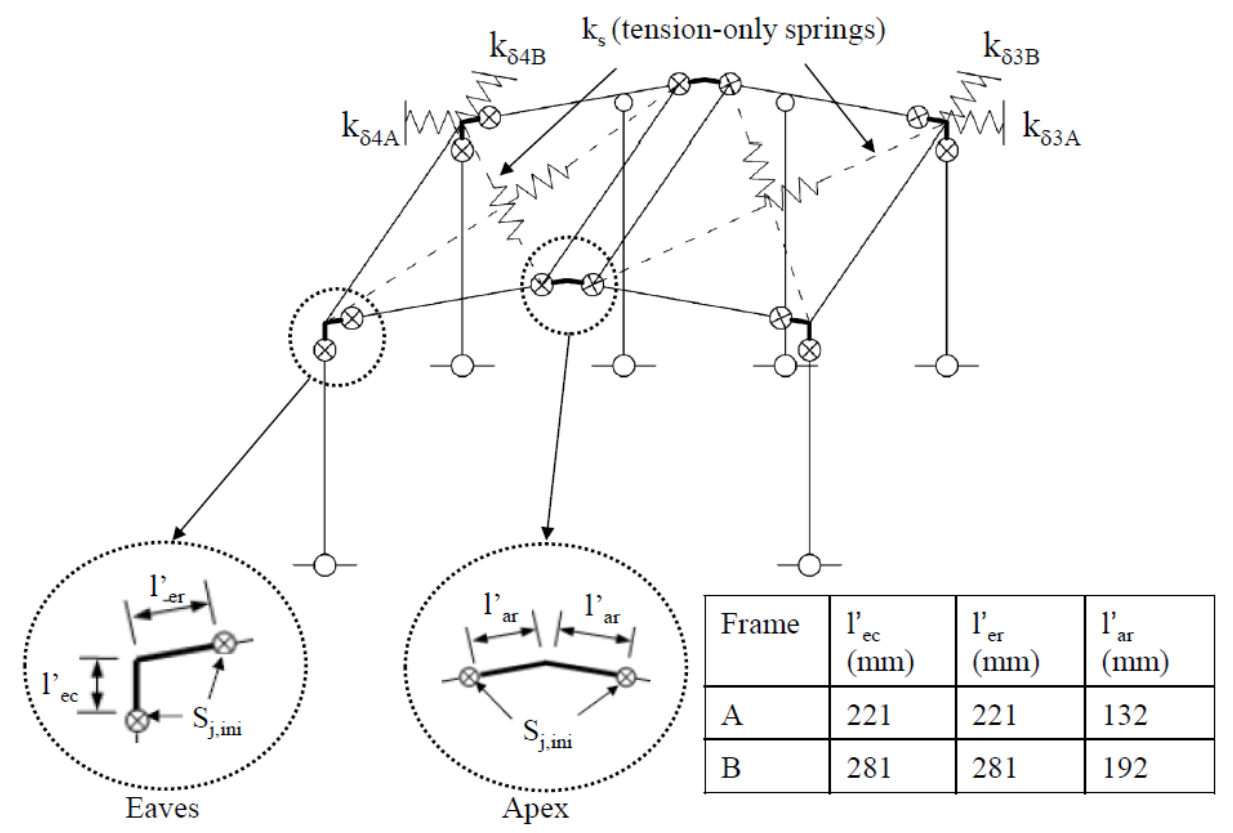

Fig.17 Frame idealisation of the full-scale tests for modelling purposes

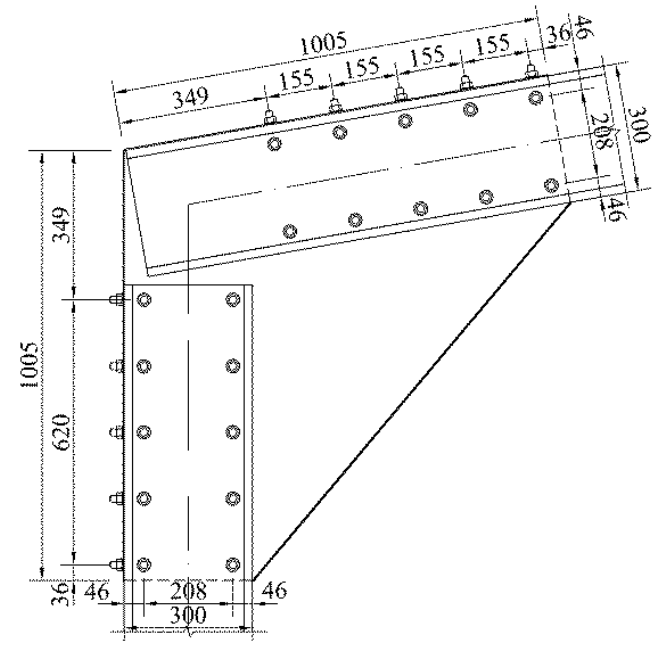

a) Eaves joint

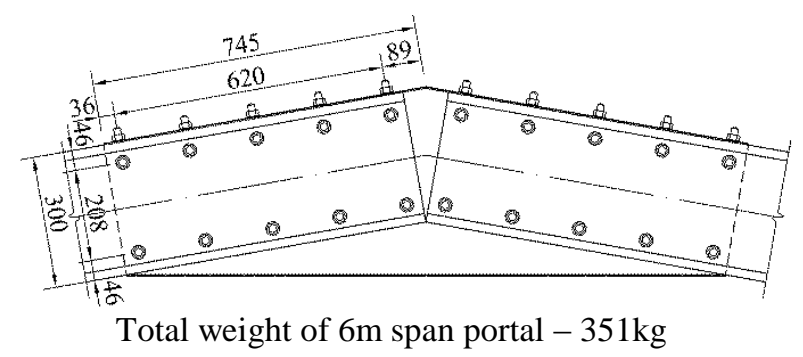

b) Apex joint

Fig.18 Details of Joint C 

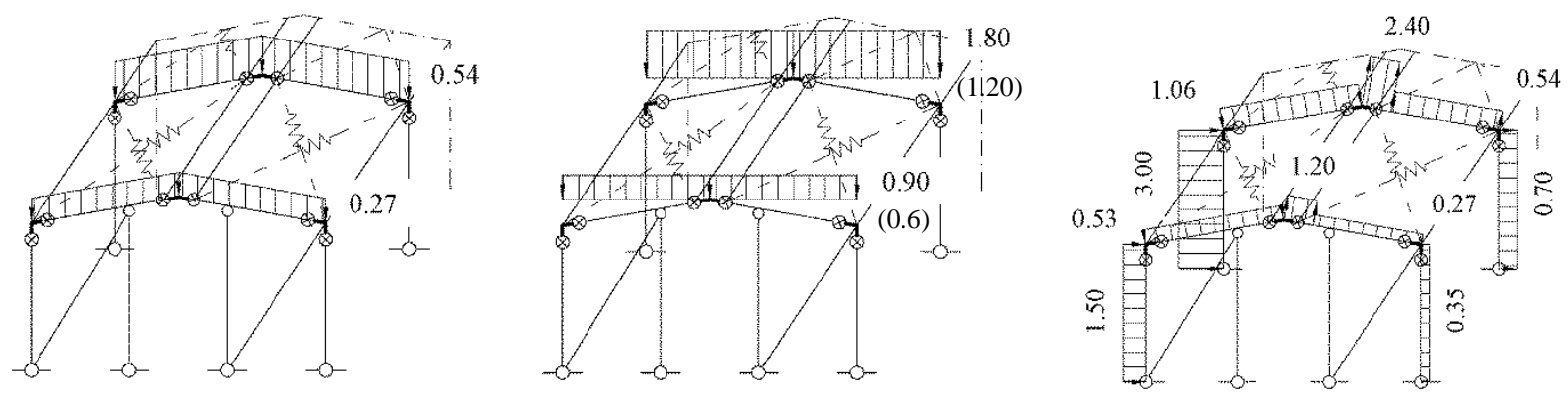

All loads in $\mathrm{kN} / \mathrm{m}$
a) Permanent action
b) Imposed load
c) Wind action

(Snow load)

Fig.19 Applied actions on the frames for design purposes

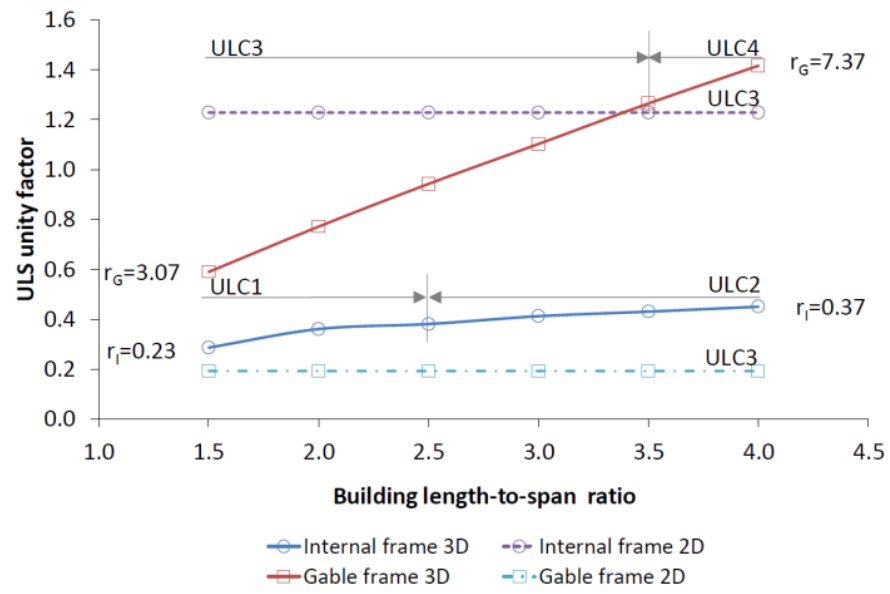

a) Buildings with Joint A

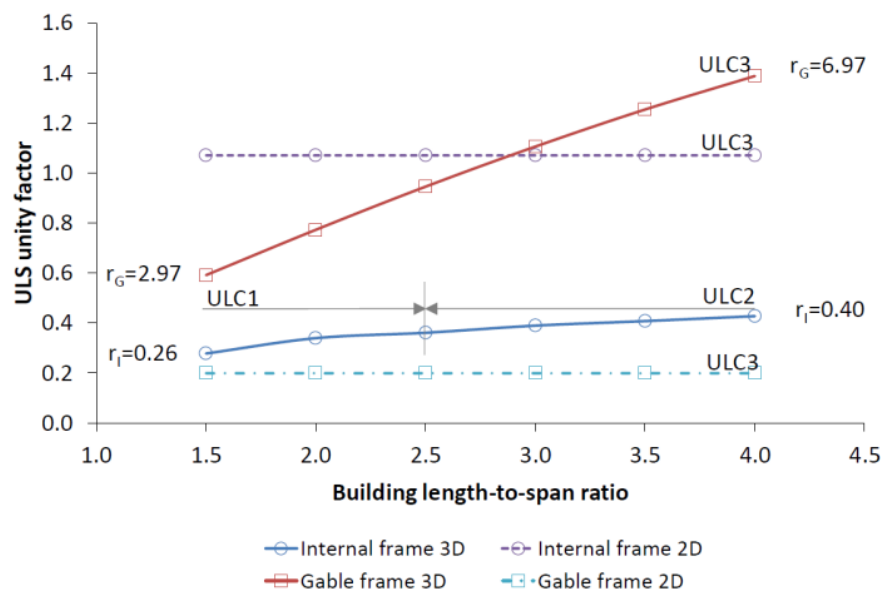

b) Buildings with Joint B 


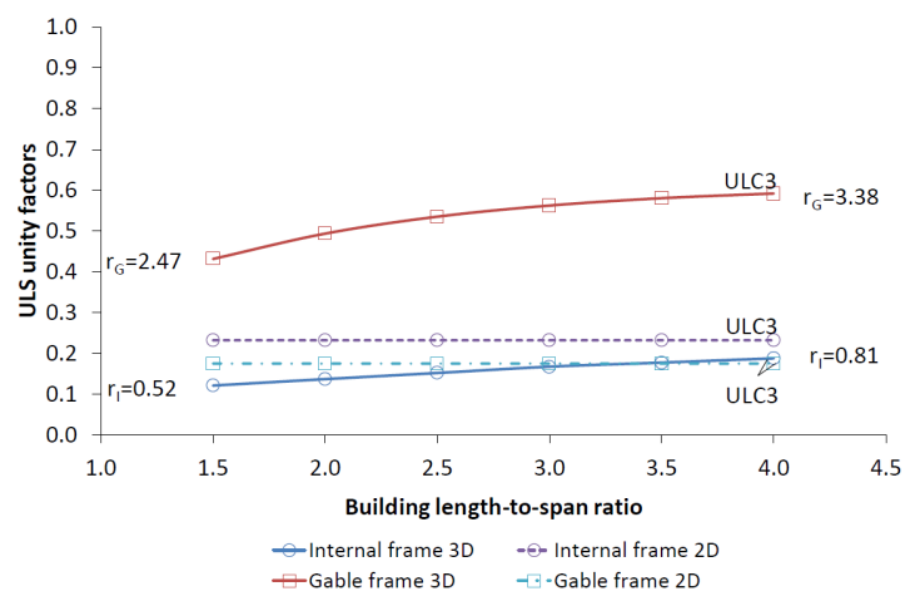

c) Buildings with two $300 \mathrm{~mm} \times 2.5 \mathrm{~mm} \mathrm{C}$ sections as intermediate columns, rafters and Joint $\mathrm{C}$

Fig.20 Ultimate limit state unity factors for critical frames

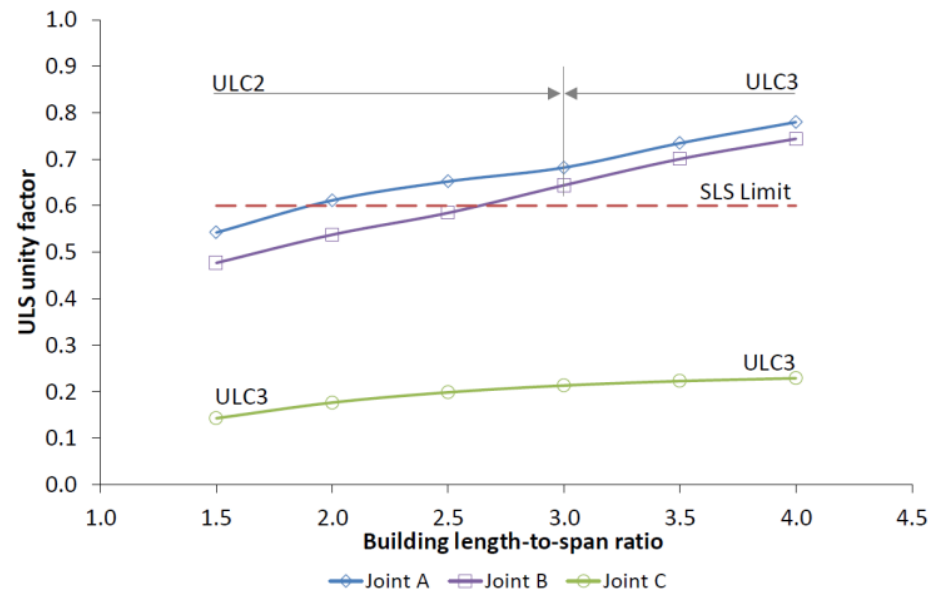

Fig.21 Ultimate limit state unity factors for critical roof panel 


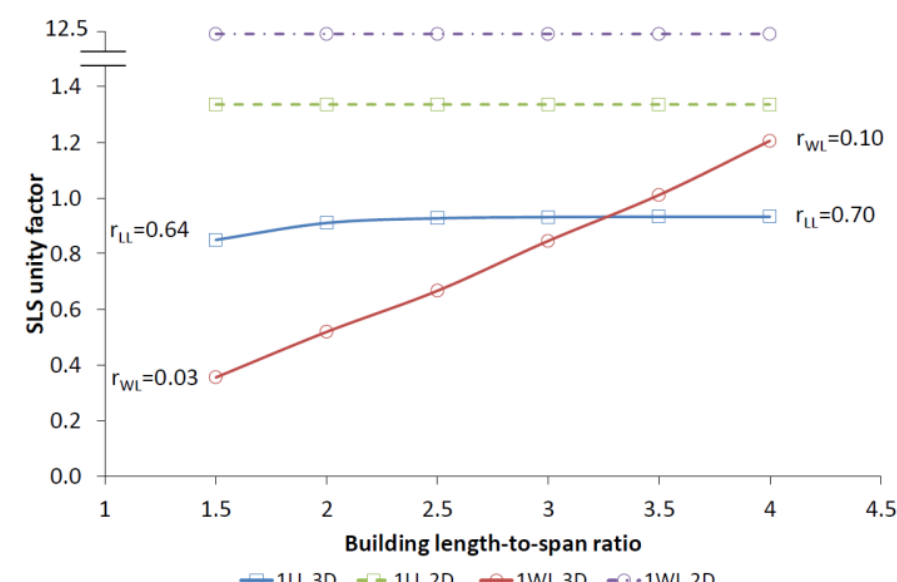

a) Buildings with Joint $\mathrm{A}$

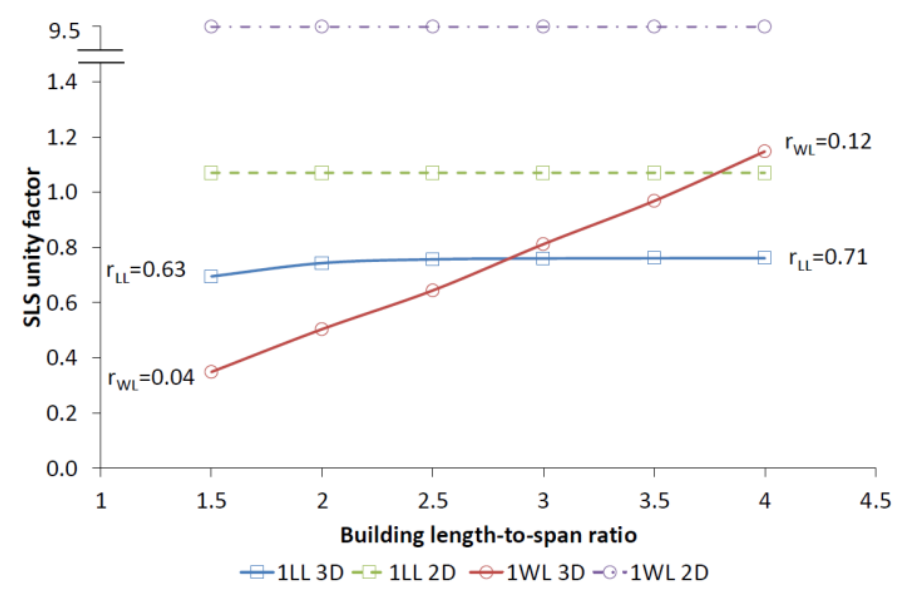

b) Buildings with Joint B

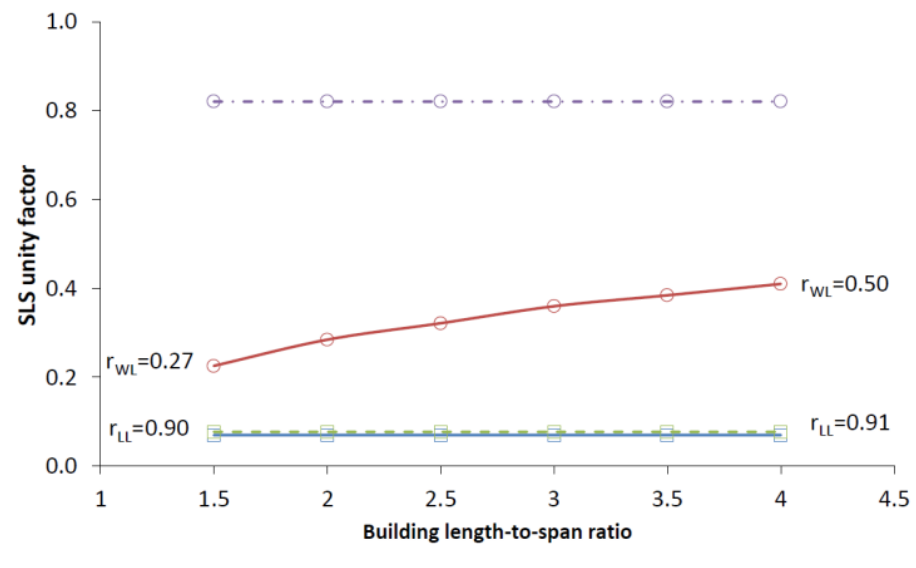

$\because 1 \mathrm{LL} 3 \mathrm{D} \quad-1 \mathrm{LL} 2 \mathrm{D} \quad-1 \mathrm{WL} 3 \mathrm{D} \quad-1 \mathrm{WL} 2 \mathrm{D}$

c) Buildings with two $300 \mathrm{~mm} \times 2.5 \mathrm{~mm} \mathrm{C}$ sections as intermediate columns, rafters and Joint $\mathrm{C}$

Fig.22 Serviceability limit state unity factors 